\title{
Innovative activity of Polish enterprises - a strategic aspect. The similarity of NACE divisions
}

\section{Edyta Bielińska-Dusza ${ }^{1}$ (D), Monika Hamerska²}

\begin{abstract}
Purpose: The innovativeness of enterprises is dependent on many variables, including decisions regarding innovation, possessed resources and competences, and the sector of their activity. Therefore, it should be considered in a strategic dimension, both at the level of the enterprise's strategic innovativeness and overall strategy. Strategic innovativeness, which is a long-term process that takes into account the interpenetration of various types of innovation together with strategic thinking, can be an effective tool for achieving high operating efficiency and maintaining a competitive advantage in the market. The analysis of literature on the subject, as well as observations, indicates that even within one industry, there are differences in this respect. A plethora of publications focusing on the problem of innovativeness in individual enterprises, sectors, industries, and regions were found. The authors aimed to divide industries classified by NACE (the Statistical Classification of Economic Activities in the European Community) divisions into homogeneous groups in terms of the innovative undertakings of said enterprises in a given industry. Methodology: The empirical part presents the results of own research using the cluster analysis method, while all calculations were performed with the use of $R$ software. Findings: It can be concluded that industries can be grouped into homogeneous clusters in terms of the share of innovative enterprises. The authors can also conclude that clusters listed on the basis of the share of innovative companies that introduced new or improved products and clusters listed on the basis of the share of innovative companies that introduced new or improved business processes are very similar. Implications for theory and practice: The combined value of the considerations presented in the paper is the possibility of obtaining supplementary information about the homogeneity of
\end{abstract}

1 Edyta Bielińska-Dusza, Ph.D., Assistant Professor, Department of Department of Strategic Analysis, Institute of Management, College of Management and Quality, Cracow University of Economics, Rakowicka 27, 31-510 Krakow, Poland, email: bielinse@uek.krakow.pl (ORCID: https://orcid.org/0000-0003-2007-8828).

2 Monika Hamerska, Ph.D., Assistant Professor, Department of International Management, Institute of Management, College of Management and Quality, Cracow University of Economics, Rakowicka 27, 31-510 Krakow, Poland, e-mail: hamerskm@uek.krakow.pl (ORCID: https://orcid.org/0000-0003-1042-8636). 
innovative activities of said enterprises in an individual NACE division. These results can be used for further in-depth analysis of individual groups. Originality and value: However, there is no study presenting the similarity between industries and their division into homogeneous groups in terms of the share of innovative enterprises. Such a gap became an inspiration for the research, which allowed for the verification of this scientific problem.

Keywords: strategy, innovation strategy, sector, NACE divisions, cluster analysis, similarity

\section{INTRODUCTION}

The issues related to the innovativeness of modern enterprises, regions and countries remain relevant, and are considered an important area of research by both theoreticians and practitioners around the world (Szopik-Depczyńska, 2018; Dyduch, 2018; Zartha et al., 2016; Dyduch, 2015; Casadeus-Masanell \& Zhu, 2013; Pichlak, 2012; Christensen, 2010; Conway \& Steward, 2009; Baldwin \& Gelletly, 2003; Pomykalski, 2001; Kay, 1996). On the one hand, the reasons for the continued interest in innovativeness can be seen in the heterogeneity and diversity of its understanding, and on the other hand, as an accelerator of change and improvement, success and wealth. However, the complexity of processes taking place in the modern world, including the dynamics of ICT technology development and the related digital revolution, shortening the life cycle of products, networking, force enterprises to make decisions in the field of innovation and implementation of innovation strategies. They allow for raising the level of their competitiveness and obtaining wider social, cultural and economic benefits for the regions in which they operate and in which they constitute an important pillar of economic, technological, and civilization development (Block, Fisch, \& van Praag, 2017; Rahimi, Rostami, Shad, \&Vafaei, 2017). Moreover, as researchers rightly point out (Nogalski \& Karpacz, 2012; Branzei \& Vertinsky, 2006), the creation of innovation strategies that are effective in shaping competitiveness requires building the innovative capacity of enterprises. This is done through the implementation of various activities in generating or absorbing new ideas and their implementation and supporting processes of innovativeness and a properly oriented action strategy. The scope of these activities is not unified and it differs not only between sectors but also between enterprises operating in the same industries.

In the subject literature concerning research in the field of innovative enterprise activity patterns, two main research trends can be distinguished (Wziątek-Kubiak, 2010). The first focuses on studying the homogeneity of enterprise innovation behaviors in various fields of industrial production 
from the perspective of how diversified the enterprise innovation strategies are (Urbankova \& Krizek, 2020; Jakimowicz \& Rzeczkowski, 2019; Srholec \& Verspagen, 2008; Llerena \& Oltra, 2002; Elliott, Greenaway, \& Hine, 2000). The second trend, which emerged in the 1990s, assumes cross-industry differentiation of enterprise innovation behaviors, and focuses on the study of the specificity of patterns in terms of the innovation of companies with high, medium, and low technological intensity. These studies contributed to the capture of the inter-sectoral differentiation of factors and patterns in the field of innovation between these two groups of enterprises (Wziątek-Kubiak, 2010; Hirsch-Kreisen, Hahn, \& Jacobson, 2008).

The above-mentioned approaches raised the question of whether industries are similar in terms of the share of innovative enterprises. The lack of such studies was the main factor that inspired the authors to take up this topic and fill the research gap.

Therefore, the aim of the paper is to divide industries, classified according to NACE (the Statistical Classification of Economic Activities in the European Community) divisions, into groups that will be homogeneous in terms of the share of innovative enterprises in a given industry based on the original concept. Based on the goal defined in this way, the following research hypotheses were formulated:

H1: Within NACE divisions, there are industries that can be grouped into clusters in terms of the share of innovative enterprises.

H2: The specified clusters include industries in which enterprises run a similar type of business.

H3: Clusters listed on the basis of the share of innovative companies that introduced new or improved products, and clusters listed on the basis of the share of innovative companies that introduced new or improved business processes, are very similar.

The aim of the study was achieved and the research hypotheses were verified on the basis of the results of an empirical study using the methods of multivariate statistical analysis. The structure of the study includes three main parts. In the first, the authors describe the concept of innovation as an unwavering subject of interest for researchers. Moreover, they pay attention to the typology of innovations and the dimensions of organizational innovativeness and describe innovativeness as the fundamental dimension of enterprise strategic innovativeness. The second part deals with the methodological aspects of the discussed issues. The third and last part presents the results of the quantitative methods used for the statistical evaluation and verification of 
the adopted goal. The research procedure includes a cluster analysis method and calculations that were performed using $\mathrm{R}$ software.

As part of the research, the classification of industries adopted by the Polish Central Statistical Office (GUS) was used, divided into service and industrial enterprises, and the classification of innovations divided into the introduction of new or improved products and new or improved business processes, including the type of innovation.

Moreover, the data used in the analysis came from a report published in January 2020 by the Polish Central Statistical Office - Innovative activity of enterprises in the years 2016-2018 (GUS, 2020). The following tables were adopted as the source of input data for the grouping procedure, which are an integral part of the indicated report: 1) Product innovations in the years 2016-2018; 2) Enterprises that introduced new or improved business processes in the years 2016-2018. This tool was also supported by a classic review of foreign and domestic literature and a narrative review. Undoubtedly, the advantage of the study is that it fills a research gap by presenting the similarity between industries and attempting to divide NACE divisions into homogeneous groups in terms of the share of innovative enterprises.

\section{LITERATURE REVIEW}

In an era of digital revolution and globalization, it is known that there is no escape from change, continuous improvement, and the implementation of innovative solutions at the level of an individual, enterprise, region, or country. However, the essence of these changes should focus on replacing those solutions that are no longer sufficient with strategies that are based on the implementation of innovative solutions, allowing in the long-term perspective the achievement of lasting competitive advantage and favoring the achievement of sustainable development (Mallinguh \& Zoltan, 2020; Szopik-Depczyńska, 2018; Okwiet, Grabara, 2016; Stawarz, 2013; Bowonder, Dambal, Kumar, \& Shirodkar, 2010; Low \& Kalafut, 2004; Gadomski, 2004). The authors do not doubt that the implementation of innovations is perceived as a key determinant of enterprise development.

Although the topic of innovation is not new, one can still observe the heterogeneity and difficulties in interpreting the very concept of innovation and a number of analyses and scientific research in this field. There are many definitions and classifications, ways of understanding it, and levels of its perception (Jansza \& Kozioł-Nadolna, 2011; Białoń, 2010). Due to its nature, there has not been one unified definition so far, there is none presently, and there will not be one in the future. It seems that, like the concept of 
technology, innovation often carries a large interpretative burden and, therefore, it is pointless to spend too much effort on attempting to solve this challenge (Bielińska-Dusza, 2020). However, for the accuracy and correctness of the research, the main assumptions in this matter should be accepted.

Innovations resulting from creative and planned activities are related to technological and non-technological areas, such as operational, organizational, process, financial, marketing, and economic. They are a key intangible asset and the main tool for improving and shaping competitiveness and are a fundamental process of organizational renewal. They arouse the interest of both practitioners and theoreticians, not only in the field of management and applied sciences, but also economists, lawyers, and politicians. Innovations are becoming the engine of change and the driving force behind changes in enterprises as well as economies, regions, and countries. With their growing importance, innovations are treated more and more widely, and today they constitute a condition for development and an inherent attribute of the enterprise (Dyduch, 2018; Szopik-Depczyńska, 2018; Łunarski, 2016; Low \& Kalafut, 2004).

Also, the issue of the typology of innovations is challenging to characterize unambiguously due to the large diversity and varied criteria of division. As a result, this division is not standardized, precise, or transparent (Penc, 1999) and numerous research and literature reviews have attempted to systematize this issue (Szopik-Depczyńska, 2018; Szatkowski, 2016; Łunarski, 2016; Dyduch, 2015, Karlik, 2013).

Due to the limitations on content, the authors present the typology contained in the Oslo Manual. This is due to the fact that this paper uses the data contained in the GUS report, which is based on the methodology developed by Eurostat and the OECD, presented in the same manual (GUS, 2020).

The Oslo Manual distinguishes four main types of innovation: 1) Product innovations - new or significantly improved compared to the previous version of a good or service, taking into account technical specification, components and materials, software, user-friendliness or other functional features; 2) Process innovations - new, significantly improved methods of producing or delivering a product, taking into account techniques, tools and/or software; 3) Marketing innovations - new marketing methods consisting of a significant change in the appearance of the product, packaging, distribution, promotion or price; 4) Organizational innovations - new organizational methods in business practice, consisting of modifications to the workplace or external relations (OECD, 2005).

When discussing the issues of comprehending and the typology of innovations, one cannot ignore the critical and unresolved issue, which is the distinction between two closely related concepts: innovation and 
innovativeness. As rightly noted by Klimas (2013), many authors (Binti et al., 2011; Jalonen, 2012; Semerciöz, Hassan, \& Aldemi, 2011) use these concepts interchangeably, while others consider them inappropriate, incorrect, or even erroneous (Lynch, Walsh, \& Harrington, 2010). Klimas (2013) refers to an interesting approach proposed by Wang and Ahmed (2004), according to which organizational innovativeness is the entire ability of an organization to introduce new products to the market, and open new markets through the appropriate configuration of strategic orientation with the innovative behavior of employees and implemented processes.

Researchers believe that the four types of innovation defined in the Oslo Manual, i.e. product, organizational, technological, and marketing innovation, are components of organizational innovativeness. They propose five dimensions of organizational innovativeness: 1) Product innovativeness; 2) Process innovativeness; 3) Behavioral innovativeness; 4) Strategic innovativeness; 5) Market innovativeness.

This proposal inspired the research conducted by Crossan and Apaydin (2010), which resulted in the identification of four dimensions of innovativeness: 1) Product innovativeness understood as the novel and pioneering nature of new products implemented on the market at the right time; 2) Process innovativeness understood as the implementation of new production methods, technological and management solutions for the improvement of production and management processes; 3) Behavioral innovativeness understood as individual, team or managerial activities aimed at building an internal culture of innovation and the overall openness of the organization to new ideas and innovations; 4) Strategic innovativeness understood as the ability of an organization to manage a bundle of ambitious goals, identify resource gaps that prevent the achievement of ambitious goals set for itself, take creative actions to minimize resource gaps, as well as innovative approaches and methods of operation necessary for entering new markets and deeper exploitation of the existing target markets.

These proposals provide an interesting perspective of the problem under study, but the conclusion is that no matter how one classifies the set, the distinguished types will interpenetrate, complement, overlap and merge into each other, while the enterprise may implement them jointly. And it may do so, often treating them as one, because the distinguished types do not constitute separate, isolated entities, but constitute an interdependent whole (Dyduch, 2015).

This is because innovativeness is the fundamental dimension of enterprise strategic innovativeness and a growth factor. Many studies have been written on the subject of innovativeness, highlighting that it is a source of organizational effectiveness but that it also initiates changes. It is a factor 
in building a competitive advantage and is not so much a feature of the country as a feature of individual enterprises (Gomułka, 2006). Numerous researchers have also attempted to answer the question of how innovative activity within a company impacts its competitiveness (e.g., Bogdanienko, 2004; Zastempowski, 2013; Lemanowicz, 2014; Prajogo \& Ahmed, 2006; Poznańska, 2002a). Most often, subject literature focuses on analyzing the innovativeness of a selected enterprise or group of enterprises, industry, economy, state or regions. Moreover, as mentioned earlier, the problem is dealt with by distinguishing within two groups: the diversity of innovativeness behaviors and homogeneity (Wziątek-Kubiak, 2010). It should also be underlined that the adopted research methodology, based on different criteria and reflecting different research perspectives, may show discrepancies in the obtained results and present them in different cross-sections. Furthermore, due to technological changes, the time period adopted for the analysis may be an interesting variable showing the nature of changes in the level of innovativeness in the long term.

Cyclical surveys conducted since 2011 by the Polish Central Statistical Office show slight changes in the innovativeness of industries over the years. In Table 1 and Table 2, five industries are presented that are the most and the least innovative in terms of the share of innovatively active enterprises.

Table 1. Innovatively active industrial enterprises in the years 2011-2018 by NACE divisions

\begin{tabular}{|c|c|c|c|}
\hline & 2016-2018 & 2014-2016 & 2011-2013 \\
\hline $\begin{array}{l}\text { The most } \\
\text { innovation }\end{array}$ & $\begin{array}{l}\text { 1. Manufacture of } \\
\text { pharmaceutical products } \\
\text { 2. Manufacture of } \\
\text { computer, electronic and } \\
\text { optical products } \\
\text { 3. Mining of coal and } \\
\text { lignite } \\
\text { 4. Manufacture of } \\
\text { electrical equipment } \\
\text { 5. Manufacture of coke } \\
\text { and refined petroleum } \\
\text { products }\end{array}$ & $\begin{array}{l}\text { 1. Mining of coal and } \\
\text { lignite } \\
\text { 2. Manufacture of } \\
\text { pharmaceutical products } \\
\text { 3. Manufacture of } \\
\text { computer, electronic and } \\
\text { optical products } \\
\text { 4. Manufacture of } \\
\text { chemicals and chemical } \\
\text { products } \\
\text { 5. Manufacture of coke } \\
\text { and refined petroleum } \\
\text { products }\end{array}$ & $\begin{array}{l}\text { 1. Manufacture of coke } \\
\text { and refined petroleum } \\
\text { products } \\
\text { 2. Manufacture } \\
\text { of pharmaceutical } \\
\text { products } \\
\text { 3. Manufacture of } \\
\text { computer, electronic } \\
\text { and optical products } \\
\text { 4. Manufacture of } \\
\text { chemicals and chemical } \\
\text { products } \\
\text { 5. Mining of coal and } \\
\text { lignite }\end{array}$ \\
\hline
\end{tabular}




\begin{tabular}{llll}
\hline & 2016-2018 & 2014-2016 & 2011-2013 \\
\hline Least & 1. Remediation activities & 1. Manufacture of & 1. Manufacture of \\
innovation & 2. Manufacture of & wearing apparel & wearing apparel \\
& wearing apparel & 2. Manufacture of & 2. Repair and \\
& 3. Manufacture of & leather and related & installation of \\
products of wood, cork, & products & machinery and \\
& straw, and wicker & 3. Repair and & equipment \\
4. Manufacture of & installation of machinery & 3. Manufacture of \\
leather and related & and equipment & products of wood, cork, \\
products & 4. Manufacture of & straw and wicker \\
& 5. Waste collection, & products of wood, cork, & 4. Manufacture of \\
treatment, and disposal & straw, and wicker & leather and related \\
& activities; materials & 5. Remediation activities & products \\
recovery & & 5. Manufacture of food \\
& & products
\end{tabular}

Source: Authors' own work, based on: GUS (2014); GUS (2018); GUS (2020).

Table 2. Innovatively active service enterprises in the years $2011-2018$ by NACE divisions

\begin{tabular}{|c|c|c|c|}
\hline & 2016-2018 & 2014-2016 & 2011-2013 \\
\hline $\begin{array}{l}\text { The most } \\
\text { innovation }\end{array}$ & $\begin{array}{l}\text { 1. Scientific research and } \\
\text { development } \\
\text { 2. Insurance, } \\
\text { reinsurance, and pension } \\
\text { funding } \\
\text { 3. Computer } \\
\text { programming and } \\
\text { consultancy activities } \\
\text { 4. Information service } \\
\text { activities } \\
\text { 5. Publishing activities }\end{array}$ & $\begin{array}{l}\text { 1. Insurance, } \\
\text { reinsurance, and pension } \\
\text { funding } \\
\text { 2. Scientific research } \\
\text { and development } \\
\text { 3. Computer } \\
\text { programming and } \\
\text { consultancy activities } \\
\text { 4. Financial service } \\
\text { activities } \\
\text { 5. Publishing activities }\end{array}$ & $\begin{array}{l}\text { 1. Insurance, } \\
\text { reinsurance, and } \\
\text { pension funding } \\
\text { 2. Scientific research } \\
\text { and development } \\
\text { 3. Computer } \\
\text { programming and } \\
\text { consultancy activities } \\
\text { 4. Financial service } \\
\text { activities } \\
\text { 5. Information service } \\
\text { activities }\end{array}$ \\
\hline $\begin{array}{l}\text { Least } \\
\text { innovation }\end{array}$ & $\begin{array}{l}\text { 1. Architectural and } \\
\text { engineering activities; } \\
\text { technical testing and } \\
\text { analysis } \\
\text { 2. Air transport } \\
\text { 3. Wholesale trade } \\
\text { 4. Postal and courier } \\
\text { activities } \\
\text { 5. Water transport }\end{array}$ & $\begin{array}{l}\text { 1. Air transport } \\
\text { 2. Land and pipeline } \\
\text { transport } \\
\text { 3. Advertising and } \\
\text { market research } \\
\text { 4. Postal and courier } \\
\text { activities } \\
\text { 5. Wholesale trade }\end{array}$ & $\begin{array}{l}\text { 1. Land and pipeline } \\
\text { transport } \\
\text { 2. Air transport } \\
\text { 3. Architectural and } \\
\text { engineering activities; } \\
\text { technical testing and } \\
\text { analysis } \\
\text { 4. Wholesale trade } \\
\text { 5. Warehousing and } \\
\text { support activities for } \\
\text { transportation }\end{array}$ \\
\hline
\end{tabular}

Source: Authors' own work, based on: GUS (2014); GUS (2018); GUS (2020). 
The analysis of the tables above provides for a general observation that the highest share of innovatively active enterprises concerns those industries in which enterprise activity is based on knowledge and those that offer knowledge-intensive services and products. These industries are saturated with knowledge in the form of technology, techniques supported by IT tools or organizational and managerial methods and techniques, which are based on up-to-date information, thanks to, for example, electronic IT tools and extensive cooperation.

The lowest innovative activity, especially industrial enterprises, results from their traditional production and low or close-to-exhaustion innovative potential (Gomułka, 2006) and insufficient financial resources and a focus on the current activities of the enterprise, rather than a well-thought-out, longterm strategy. It should be noted that in both industrial and service enterprises, the decrease and the increase in innovativeness might be a consequence of the amount of financial outlays. Moreover, enterprises more often introduce business process innovations than product innovations. This is mainly related to the implementation of new or improved methods of goods production or service development and new methods of task division, decision-making improvements, or human resource management. Additionally, the higher the level of technology advancement there is in a given industry, the greater the percentage of enterprises implementing innovations (GUS, 2020).

Moreover, it seems that such activities in individual industries are characterized by diversity, which is consistent but not homogeneous. The issue of innovativeness in Polish enterprises is the center of many academic studies (Lemanowicz, 2014; Grzybowska, 2012; Mizgajska, 2002; Poznańska, 2002b; Włodarczyk, 2012; Zastempowski, 2016). However, the research focuses on the ordering of enterprises and industries in terms of their innovativeness. Still, there are no studies that show the similarity of sectors regarding the share of innovatively active enterprises. Such an approach to the problem could also be the basis for further research, which would allow for better recognition of this area. Therefore, in the further part of this study, the authors focus on the first issue: the grouping of industries similar to each other in terms of the share of enterprises introducing new or improved products and business processes. 


\section{METHODOLOGY}

\section{The scope and the goals of the analysis}

According to the definition given by the Polish Central Statistical Office, an innovative enterprise in the field of product innovations and business processes is an enterprise that introduced at least one innovation to the market during the period considered, in the form of a new or improved product, or new or improved business process (GUS, 2020). A new product is a product or service that differs significantly in terms of its features or purpose from the products previously manufactured by the enterprise. Improvements to existing products include changes to materials, components and more features that make these products work better. Product innovation in the field of services is about introducing significant improvements in the way the services are provided, by adding new functions or features to existing services or by introducing completely new services. Concurrently, innovation of business processes is the introduction of new solutions or the improvement of existing business processes in the enterprise within one or more business functions, which significantly change business processes used so far (GUS, 2020).

The data used in the analysis come from a report published in January 2020 by the Polish Central Statistical Office - Innovative activity of enterprises in the years 2016-2018 (GUS, 2020). The following tables were adopted as the source of input data for the grouping procedure, which are an integral part of the indicated report: 1) Product innovations in years 2016-2018; 2) Enterprises that introduced new or improved business processes in the years 2016-2018.

\section{Stages of conducted analysis}

Research on the homogeneity of industries was carried out separately for two groups of enterprises: industrial and service. The conducted research focused on 24 NACE divisions for industrial enterprises and 33 NACE divisions for service enterprises. Because industrial enterprises belonging to the NACE division of Extraction of crude petroleum and natural gas did not introduce a new or improved product or business process in the period under study, they were not included in the analysis.

The analysis was carried out according to the steps presented in Table 3. 
Table 3. Stages of conducted analysis

\begin{tabular}{lll}
\hline Stages & Goals & Variables \\
\hline Stage 1. & $\begin{array}{l}\text { Designating groups of } \\
\text { industries similar to each } \\
\text { other }\end{array}$ & $\begin{array}{l}\text { 1. Share of enterprises that introduced new or } \\
\text { improved products; }\end{array}$ \\
2. Share of enterprises that introduced new or \\
improved business processes.
\end{tabular}

Source: Authors' own work, based on: GUS (2020).

\section{Research procedure - cluster analysis}

In order to identify NACE divisions similar to each other in terms of the features listed in individual stages of the research process, cluster analysis was used. All calculations were performed using R software. 
Cluster analysis is a term used to describe a family of statistical procedures specifically designed to discover homogenous groups within complex data sets. The objective of cluster analysis is to group objects into clusters, so that objects within one cluster share more in common with one another than they do with the objects of other clusters. Thus, the purpose of the analysis is to arrange objects into relatively homogeneous groups based on multivariate observations (Paul \& Gore, 2000). A hierarchical method was used in the presented research. This method, in general, tries to decompose the dataset of n objects into a hierarchy of groups (Bora \& Gupta, 2014). This hierarchical decomposition can be represented by a tree structure diagram called a "dendrogram", whose root node represents the whole dataset. Each leaf node is a single object of the dataset. The clustering results can be obtained by cutting the dendrogram at different levels (Soni \& Ganatra, 2012).

The clustering of similar NACE divisions in terms of the share of innovative enterprises was carried out in the following steps:

1) Cosine distance was determined (due to data concerning the share of enterprises in the analyzed NACE divisions). Cosine similarity measures the similarity between two vectors of an inner product space. It is measured by the cosine of the angle between two vectors and it determines whether two vectors are pointing in roughly the same direction (Han, Kamber, \& Pei, 2012). Similarity increases when the distance between two vectors decreases. The cosine method implemented in the philentropy package ( $R$ software) was used to determine the cosine similarities. The formula to find the cosine similarity is as follows (Drost, 2018):

$$
S=\frac{\sum_{i-1}^{N}\left(P_{i} * Q_{i}\right)}{\sqrt{\sum_{i=1}^{N} P_{i}^{2} *} \sqrt{\sum_{i=1}^{N} Q_{i}^{2}}}
$$

and the formula of Cosine distance is expressed as: 1-cosine similarity.

2) For cluster analysis, the agglomeration method of hierarchical clustering (Ward algorithms) was used. The Ward algorithm was implemented in agnes from the cluster library (R software). Ward's method minimizes the increase in total within-cluster sum of squared errors (Szekely \& Rizzo, 2005). Clustering results were presented using a dendrogram.

3) The number of classes was specified. The silhouette index was adopted to assess the quality of the division. This silhouette shows which objects lie well within their cluster, and which ones are merely somewhere in between clusters. The silhouette index allows an assessment of the relative quality of the clusters and an overview of the data configuration. The average silhouette width provides an evaluation of clustering validity 
and it might be used to select an "appropriate" number of clusters (Rousseeuw, 1987). The silhouette index was implemented in silhouette in cluster library (R software).

4) The similarity between the two data classifications was measured using the Rand index. The Rand index has a value between 0 and 1, with 0 indicating that the two data clusterings do not agree on any pair of points and 1 indicating that the data clusterings are exactly the same. The Rand index was implemented in fossil package (R software).

\section{RESULTS AND DISCUSSION}

\section{Analysis of the similarity of industries in terms of the share of innovative service enterprises}

\section{Innovation activity of service enterprises}

The cluster analysis of NACE divisions similar to each other in terms of the share of service enterprises that introduced new or improved products or business processes was the main goal of this stage of the analysis. The following variables were included in the analysis: total share of service enterprises that introduced new or improved products, and total share of service enterprises that introduced new or improved business processes. For the cluster analysis, Ward's algorithm was used with the Cosine distance. The dendrogram obtained as a result is presented in Figure 1. 


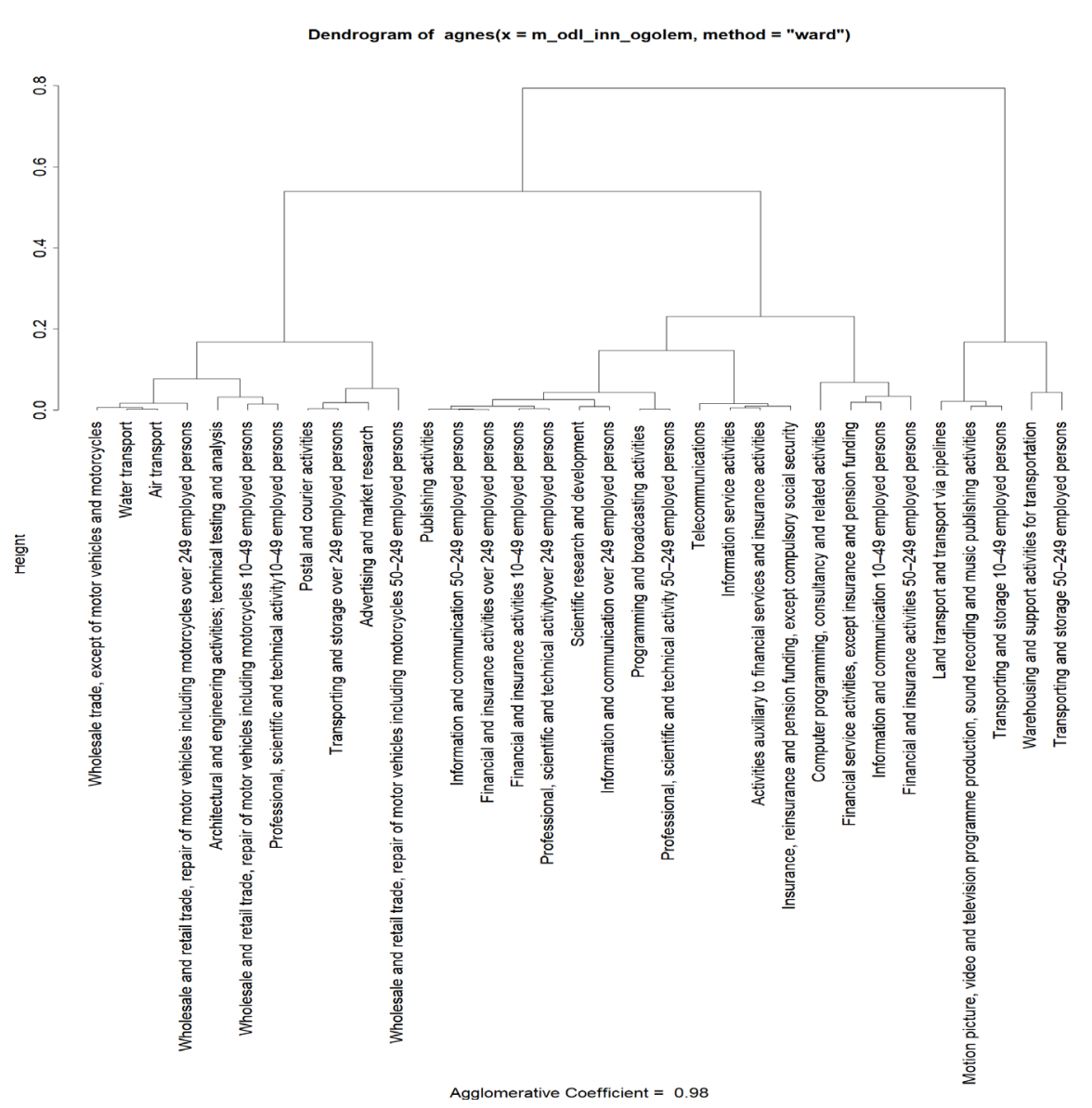

Figure 1. The similarity of NACE divisions with respect to the total share of service enterprises that introduced new or improved products or business processes

The next step in the analysis was to determine the appropriate number of clusters. The silhouette index was used to assess the quality of the division. As the results in Table 4 show, the best quality was found in the division of the surveyed population into three clusters. The silhouette index was 0.79 , which means that strong structure has been found. 
Table 4. The silhouette index for the similarity of NACE divisions with respect to the total share of service enterprises that introduced new or improved products or business processes

\begin{tabular}{llllll}
\hline & $\mathbf{2}$ groups & $\mathbf{3}$ groups & $\mathbf{4}$ groups & $\mathbf{5}$ groups & $\mathbf{6}$ groups \\
\hline $\begin{array}{l}\text { The } \\
\text { silhouette } \\
\text { index }\end{array}$ & 0.6532158 & 0.7992131 & 0.6910298 & 0.6754593 & 0.6865722 \\
\hline
\end{tabular}

Figure 2 shows the calculated coefficients for all objects and values aggregated for every cluster. As the results show, all three clusters are of high quality.

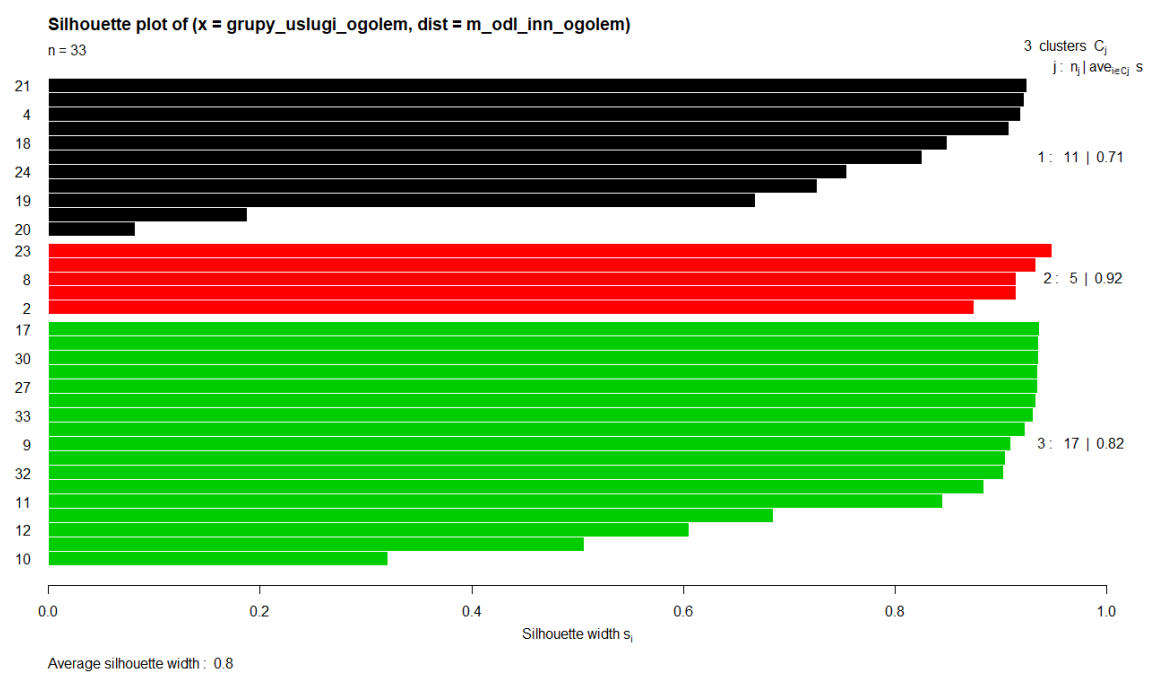

Figure 2. The silhouette index for three clusters of similar NACE divisions with respect to the total share of service enterprises that introduced new or improved products or business processes

Table 5 presents the NACE divisions divided into three clusters. Based on the tables published by the Polish Central Statistical Office (GUS, 2020), it can be indicated that the third cluster is characterized by a high share of enterprises that introduce both new and improved products and business processes and contains 17 NACE divisions. The highest share in introducing product and business innovations concerns enterprises belongs to the NACE division:

Insurance, reinsurance and pension funding except compulsory social security and amounts to $50.7 \%$ for products innovations and $77.6 \%$ for business 
innovations. The second NACE division with the highest share is: Financial and insurance activities over 249 employed persons with a share of $42 \%$ for products innovations and $56.5 \%$ for business innovations.

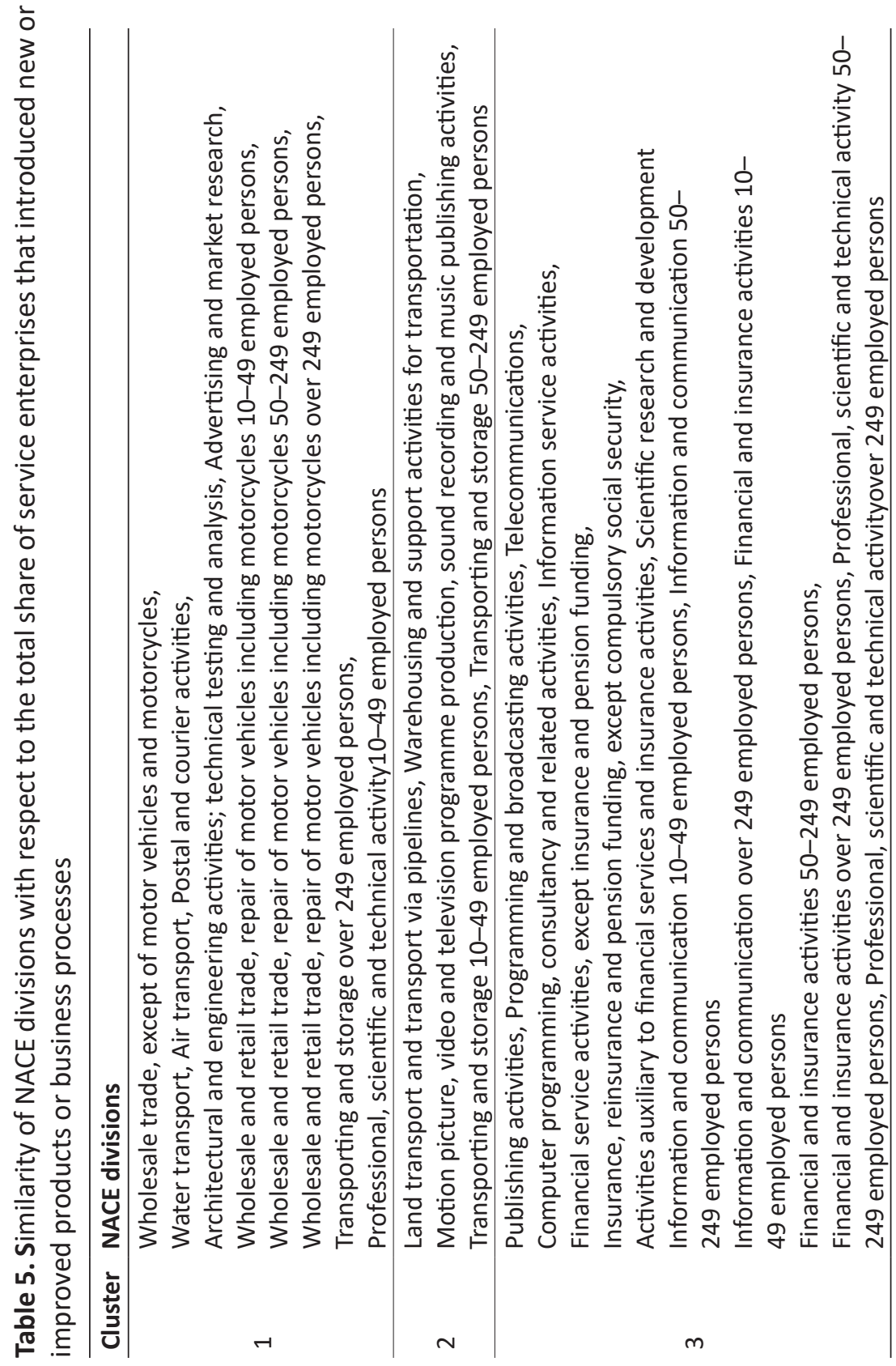

The Evolution of Strategic Management: Challenges in Theory and Business Practice Tomasz Kafel \& Bernard Ziębicki (Eds.) 
The second cluster is the smallest and contains only 5 NACE divisions, mainly related to transport activities, warehousing, activities supporting transport, presented by enterprises whose share in introducing new or improved products is rather low. When it comes to introducing new or improved business processes, 3 out of 5 NACE divisions are characterized by an average share. Attention should be paid to the two NACE divisions: Land transport and transport via pipelines (share of $3.7 \%$ for product innovations and $11.7 \%$ for business innovations) and Transporting and storage 10-49 employed persons (share of 3.2\% for products innovations and $10.7 \%$ for business innovations), which have the lowest share in both the introduction of new or improved products and business processes.

The first cluster contains 11 NACE divisions, where the share of enterprises introducing product innovations is rather at an average level, with the three clusters of the lowest share being: Whole trade, except of motor vehicles and motorcycles (7.5\%), Postal and courier activities (7.3\%), Whole trade and retail trade, repair of motor vehicles including motorcycles 10-49 employed persons (6.7\%). These industries are also characterized by a low share of enterprises in the introduction of new or improved business processes. This share is accordingly: $14.8 \%, 17.1 \%$, and $12 \%$.

\section{Innovation activity of service enterprises that introduced new or improved products}

The cluster analysis of NACE divisions similar to each other in terms of the share of service enterprises that introduced new or improved products was the main goal of this stage of the analysis. The following variables were included in the analysis:

1) Share of enterprises that introduced new or improved goods.

2) Share of enterprises that introduced new or improved services.

3) Share of enterprises that introduced new or improved goods or services new to the market.

4) Share of enterprises that introduced new or improved goods or services new only to the enterprise.

For the cluster analysis, Ward's algorithm was used with the Cosine distance. The dendrogram obtained as a result is presented in Figure 3. 


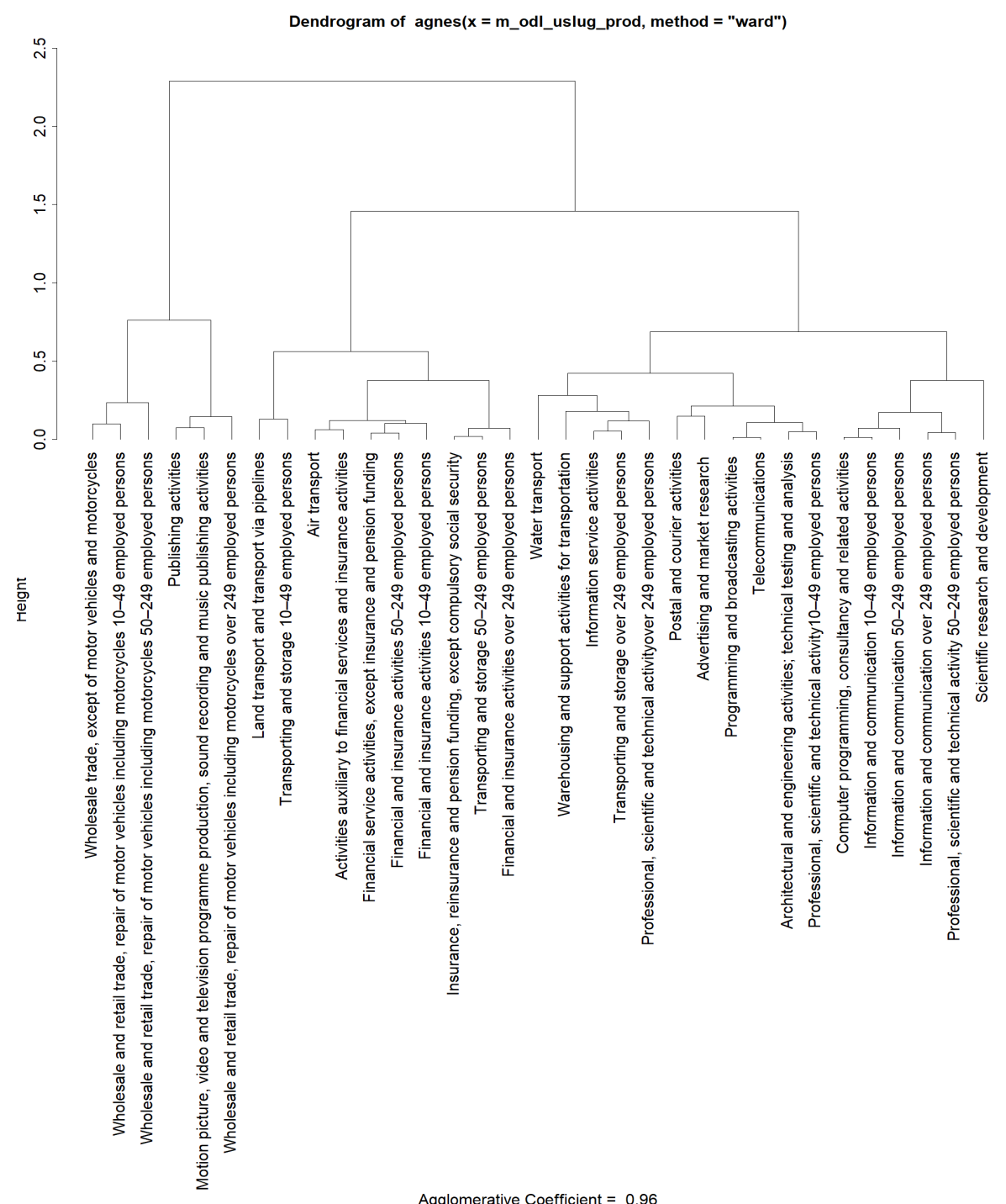

Agglomerative Coefficient $=0.96$

Figure 3. The similarity of NACE divisions with respect to the total share of service enterprises that introduced new improved products

The next step in the analysis was to determine the appropriate number of clusters. The silhouette index was used to assess the quality of the division. As the results in Table 6 show, the best quality was found in the division of the surveyed population into two and three clusters. The silhouette index was accordingly 0.6805 and 0.6738 . 
Table 6. The silhouette index for the similarity of NACE divisions with respect to the total share of service enterprises that introduced new or improved products

\begin{tabular}{lccccc}
\hline & 2 groups & 3 groups & 4 groups & $\mathbf{5}$ groups & $\mathbf{6}$ groups \\
\hline $\begin{array}{l}\text { The } \\
\text { silhouette } \\
\text { index }\end{array}$ & 0.6805194 & 0.6738426 & 0.5775993 & 0.5036341 & 0.4265721 \\
\hline
\end{tabular}

Figure 4 shows the calculated coefficients for all objects and values aggregated for every cluster. As the results show, one of the clusters is of high quality and the second one presents a reasonable structure. In the case of division into three clusters, as presented in Figure 5, one group is characterized by a reasonable structure. The other two groups present a high quality of cluster structure.

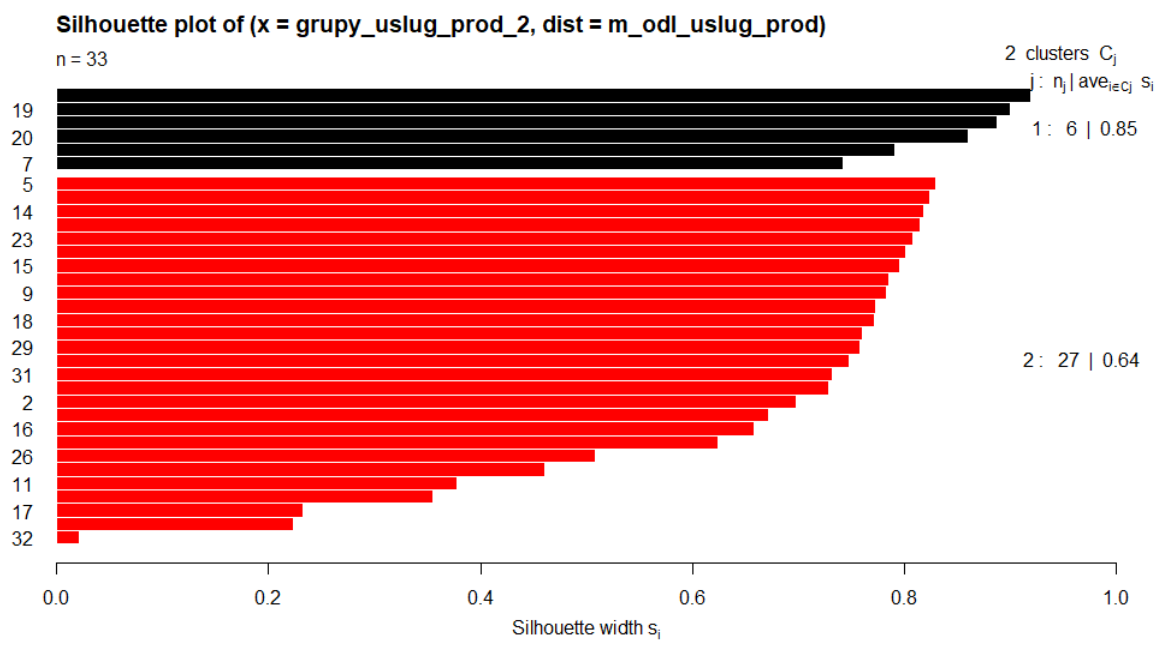

Average silhouette width : 0.68

Figure 4. The silhouette index for two clusters of similar NACE divisions with respect to the total share of service enterprises that introduced new or improved products 


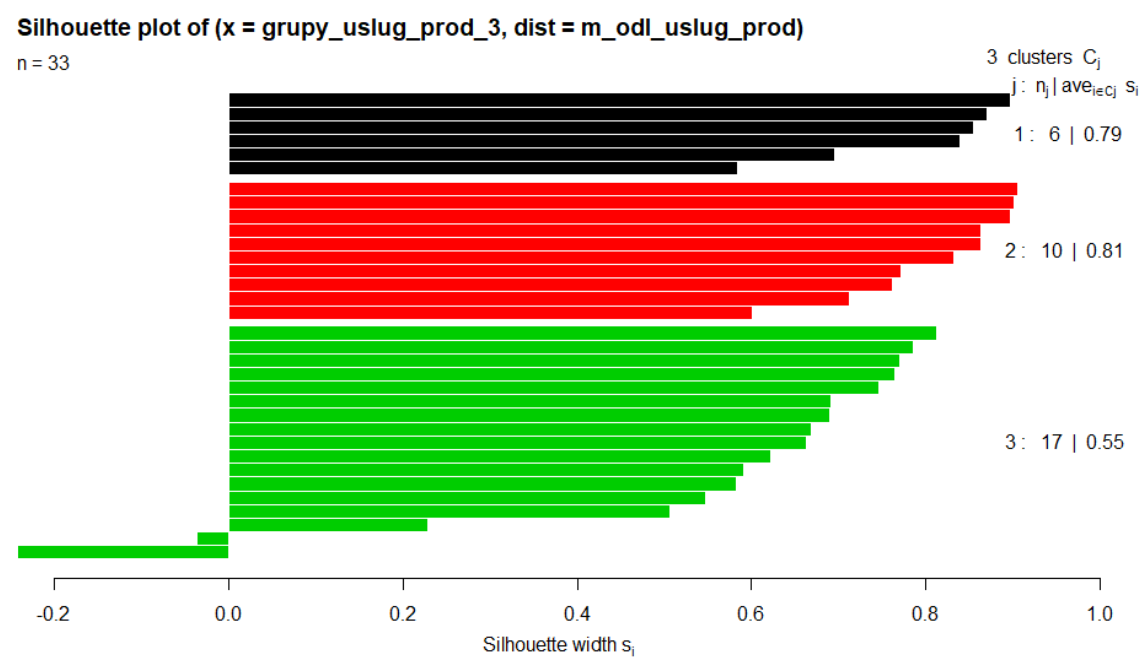

Average silhouette width : 0.67

Figure 5. The silhouette index for three clusters of similar NACE divisions with respect to the total share of service enterprises that introduced new or improved products

According to the results, Table 7 shows the grouping of NACE divisions divided into two clusters. The first cluster contains 6 NACE divisions. Based on the tables published by the Polish Central Statistical Office (GUS, 2020), it can be indicated that the first cluster is characterized by a similar value of the share of enterprises that introduce new or improved goods and share of enterprises introducing new or improved services with a slight advantage in favor of the share of enterprises that introduce new or improved goods. NACE divisions belonging to the first cluster are also characterized by the fact that the share of enterprises, which introduced new or improved goods or services new only to the enterprise, is higher than the share of enterprises that introduced new or improved goods or services new to the market. The second cluster contains 27 NACE divisions, always characterized by a higher share of enterprises introducing new or improved services rather than products. 


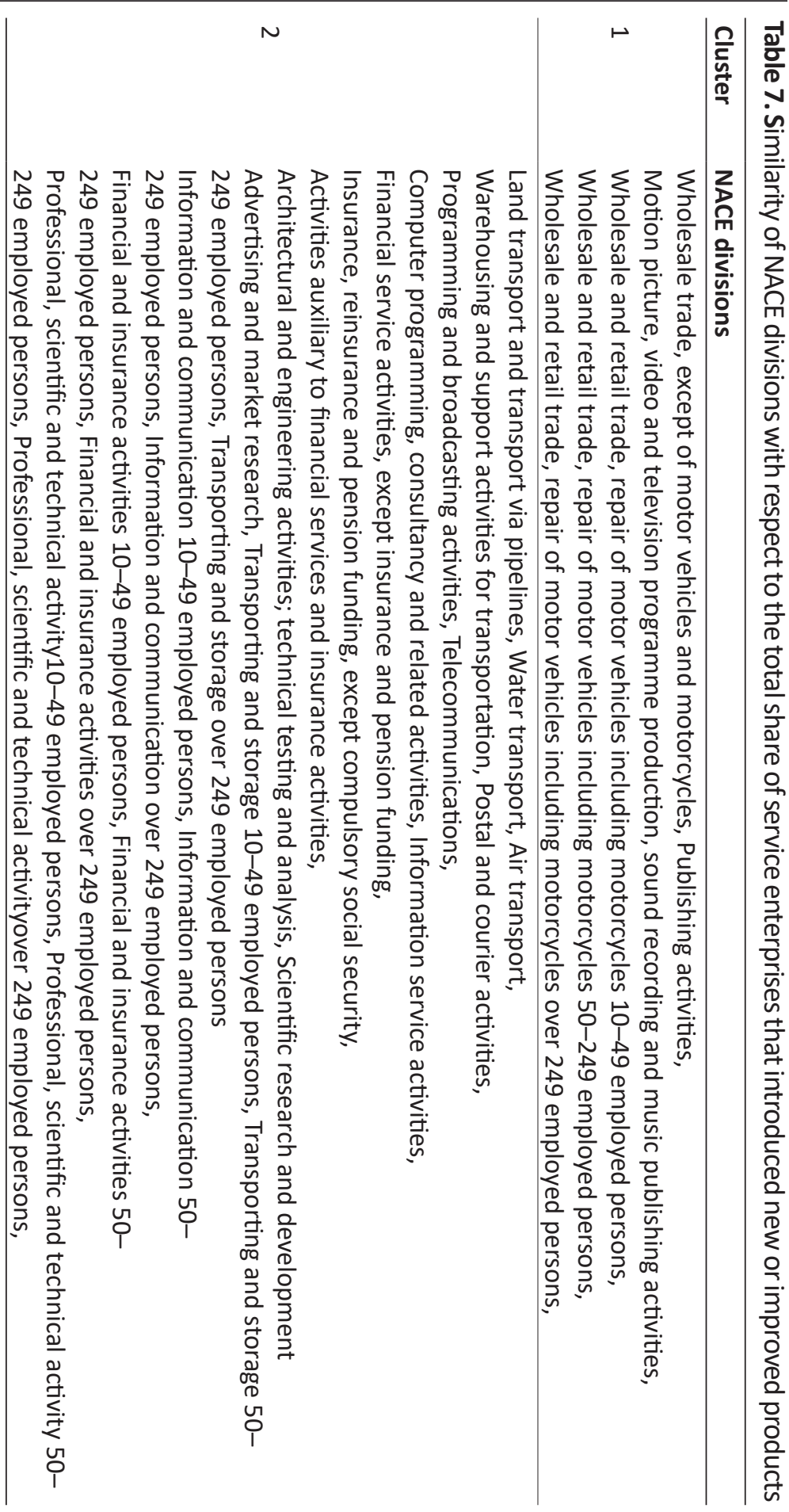


Innovation activity of service enterprises that introduced new or improved business processes

The cluster analysis of NACE divisions similar to each other in terms of the share of service enterprises that introduced new or improved business processes was the main goal of this stage of the analysis. The analysis included variables related to the share of service enterprises that introduced new or improved methods for:

1) Producing goods or providing services (including methods for developing goods or services).

2) Logistics, delivery or distribution.

3) Information processing or communication.

4) Accounting or other administrative operations.

5) Business practices for organizing procedures or external relations.

6) Organizing work responsibility, decision making or human resource management.

7) Marketing methods for promotion, packaging, pricing, product placement or after sales services.

For the cluster analysis, Ward's algorithm was used with the Cosine distance. The dendrogram obtained as a result is presented in Figure 6. 


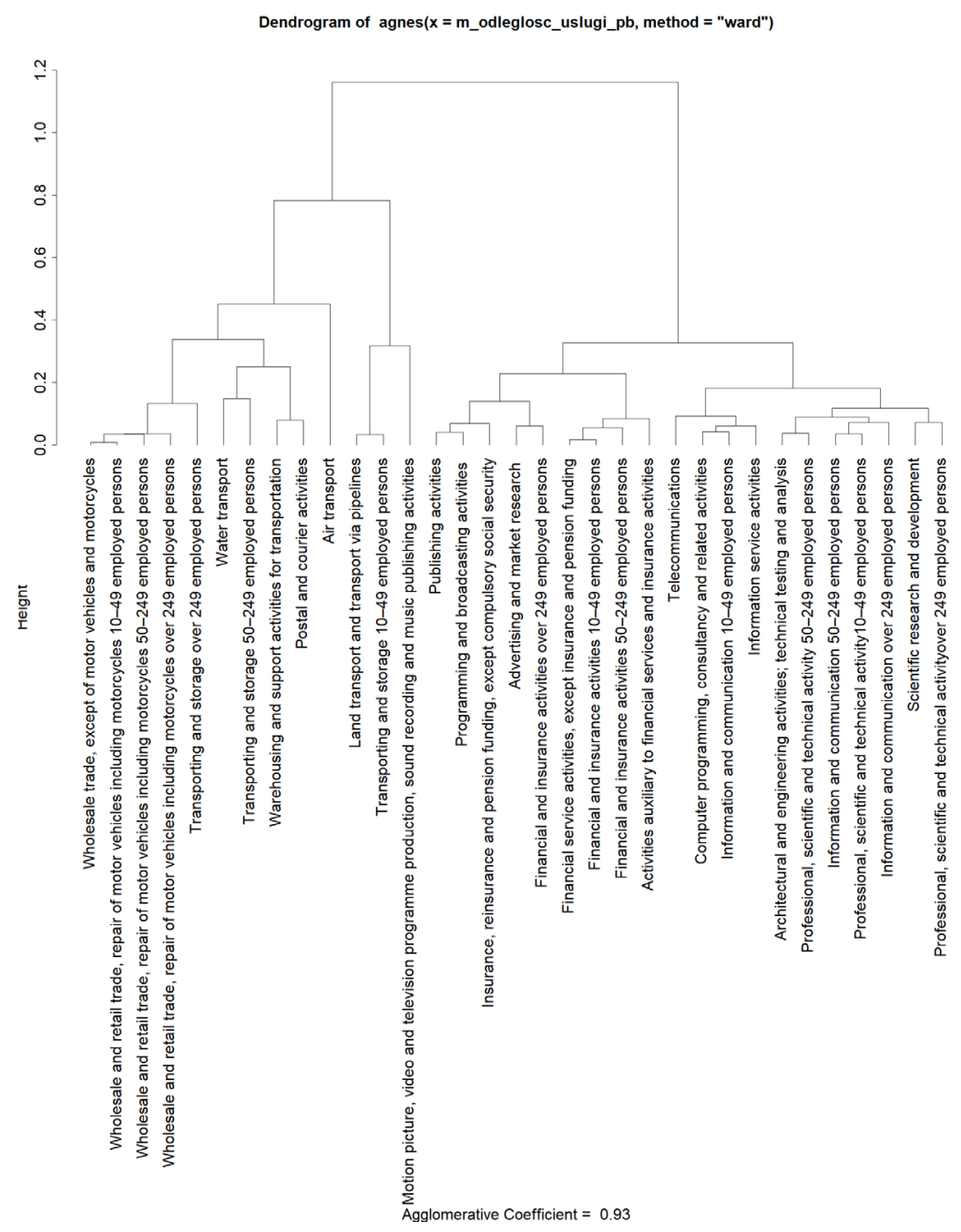

Figure 6. The similarity of NACE divisions with respect to the total share of service enterprises that introduced new or improved business processes

The next step in the analysis was to determine the appropriate number of clusters. The silhouette index was used to assess the quality of the division. As the results show, the best quality was found in the division of the surveyed population into two clusters. Results of the analysis are presented in Table 8. 
Table 8. The silhouette index for the similarity of NACE divisions with respect to the total share of service enterprises that introduced new or improved business processes

\begin{tabular}{lccccc}
\hline & $\mathbf{2}$ groups & $\mathbf{3}$ groups & $\mathbf{4}$ groups & $\mathbf{5}$ groups & $\mathbf{6}$ groups \\
\hline $\begin{array}{l}\text { The } \\
\text { silhouette } \\
\text { index }\end{array}$ & 0.5185402 & 0.4637078 & 0.4671621 & 0.3755261 & 0.2079042 \\
\hline
\end{tabular}

Figure 7 shows the calculated coefficients for all objects and values aggregated for every cluster. As the results show, one of the clusters is of high quality but the structure of the second one has very low quality.

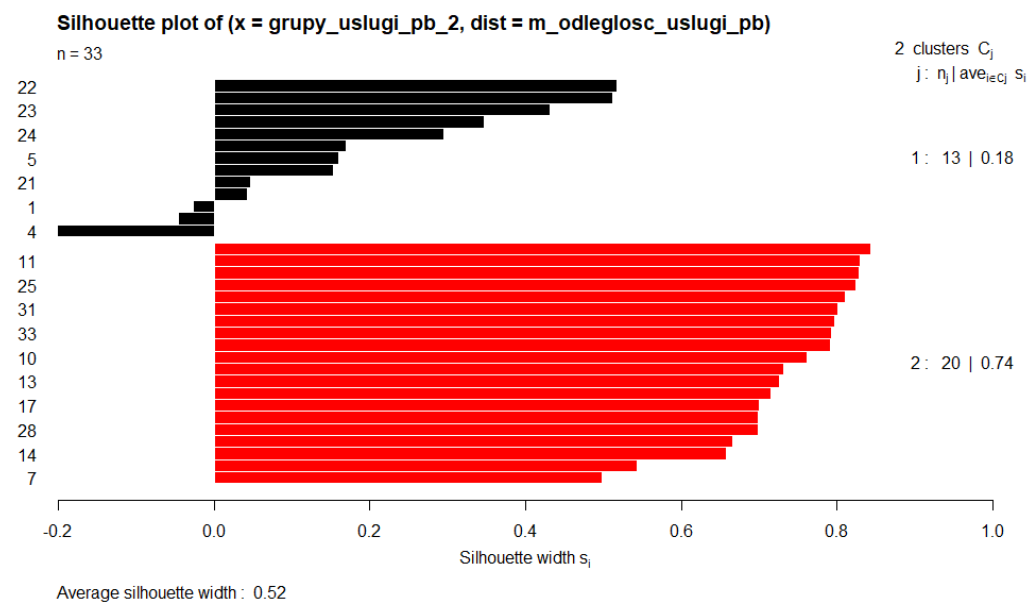

Figure 7. The silhouette index for two clusters of similar NACE divisions with respect to the total share of service enterprises that introduced new or improved business processes

According to the results, Table 9 shows the grouping of NACE divisions divided into two clusters. The first cluster contains 13 NACE divisions and the second one contains 20 NACE divisions. The first cluster is characterized by a rather lower share of enterprises that introduced new or business processes and the second one contains NACE divisions such as: Insurance, reinsurance and pension funding, except compulsory social security and Financial and insurance activities over 249 employed persons where total share of service enterprises is the highest in introducing any kind of business process innovation. 


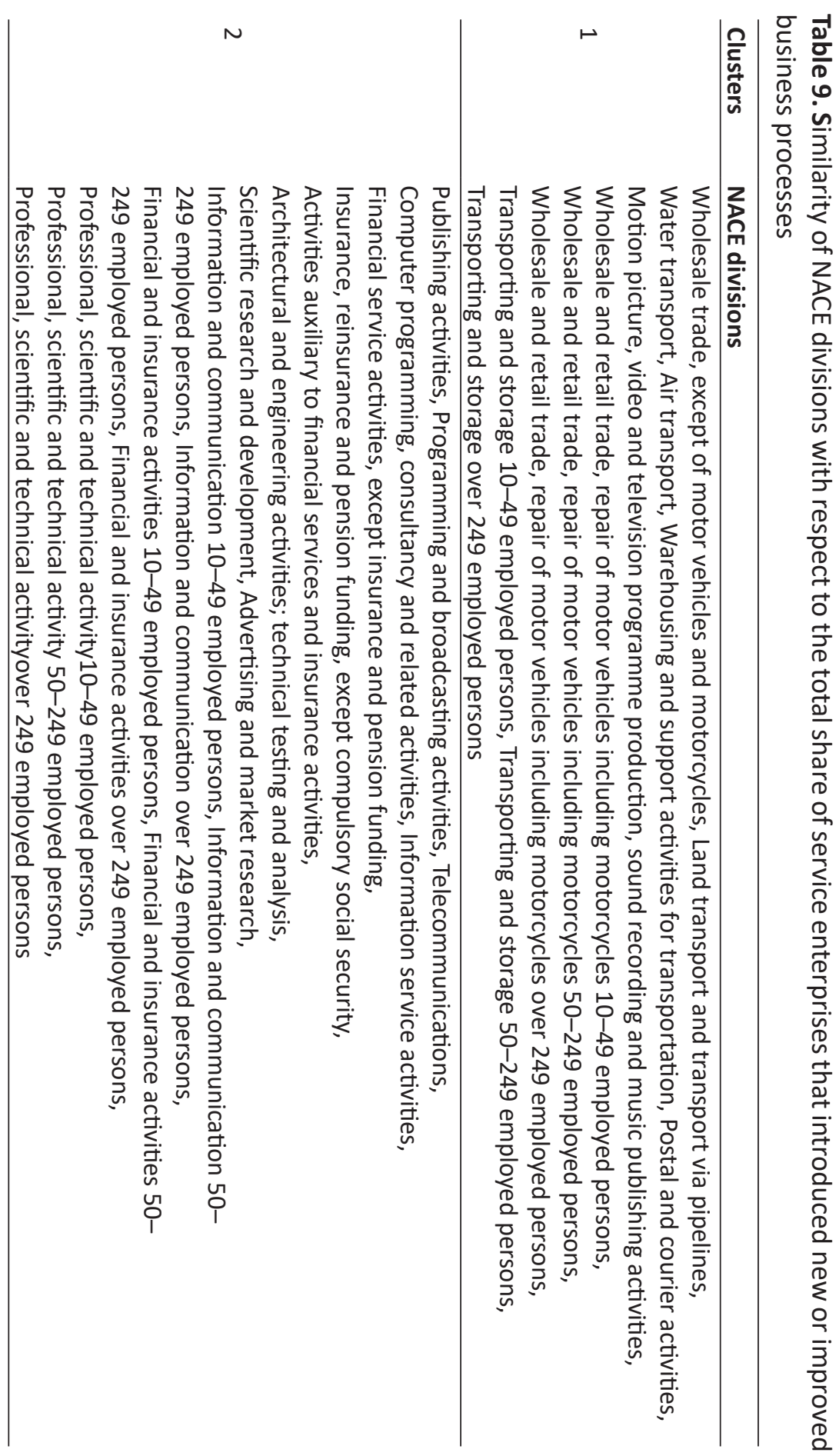


Analysis of the similarity of NACE divisions in terms of the share of innovative industrial enterprises

\section{Innovation activity of industrial enterprises}

The cluster analysis of NACE divisions similar to each other in terms of the share of industrial enterprises that introduced new or improved products or business processes was the main goal of this stage of the analysis. The following variables were included in the analysis: total share of industrial enterprises that introduced new or improved products and total share of industrial enterprises that introduced new or improved business processes.

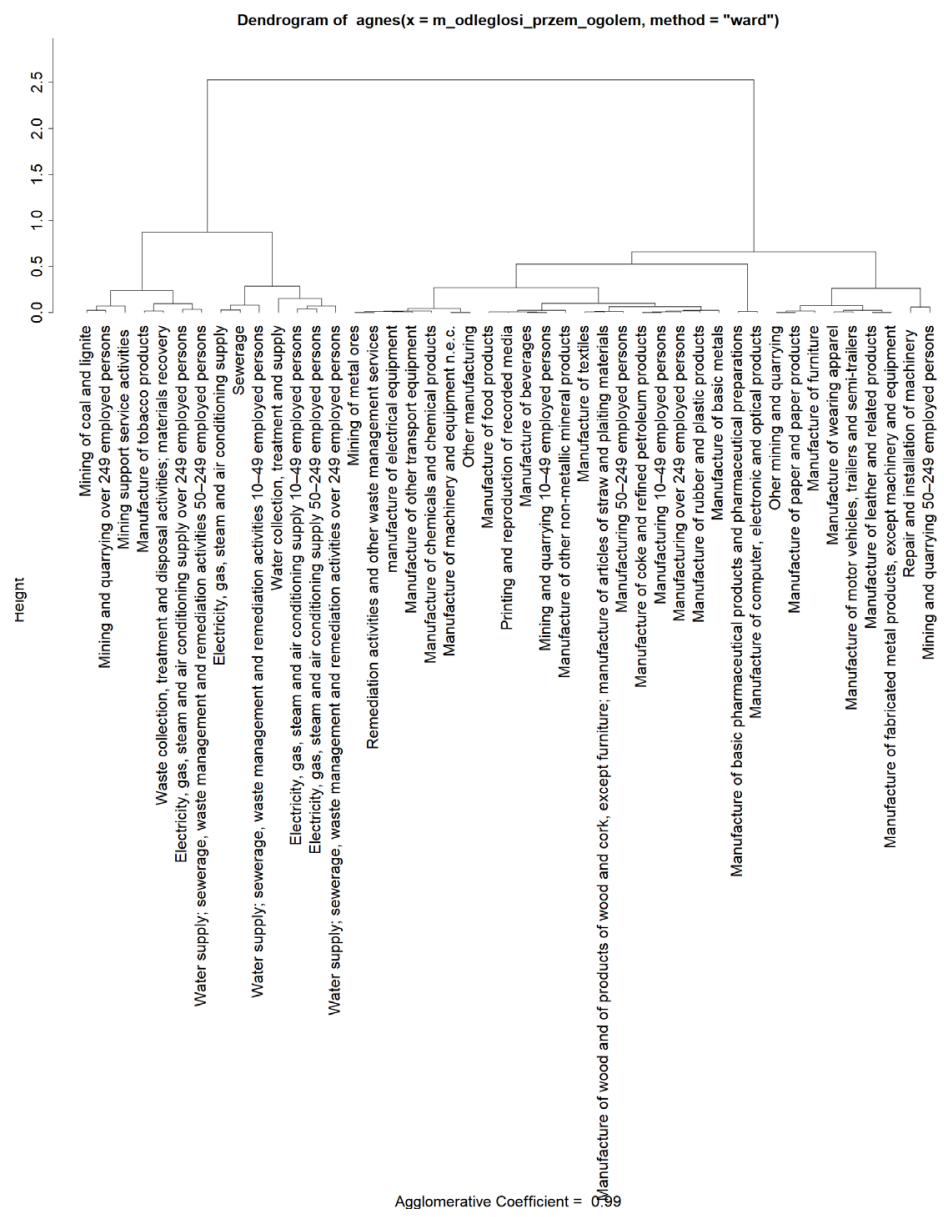

Figure 8. The similarity of NACE divisions with respect to the total share of industrial enterprises that introduced new or improved products or business processes 
For the cluster analysis, Ward's algorithm was used with the Cosine distance. The dendrogram obtained as a result is presented in Figure 8.

The next step in the analysis was to determine the appropriate number of clusters. The silhouette index was used to assess the quality of the division. As the results in Table 10 show, the best quality was found in the division of the surveyed population into two clusters. The silhouette index was 0.90 , which means that a strong structure has been found.

Table 10. The silhouette index for the similarity of NACE divisions with respect to the total share of industrial enterprises that introduced new or improved products or business processes

\begin{tabular}{llllll}
\hline & $\mathbf{2}$ groups & $\mathbf{3}$ groups & $\mathbf{4}$ groups & $\mathbf{5}$ groups & $\mathbf{6}$ groups \\
\hline $\begin{array}{l}\text { The silhouette } \\
\text { index }\end{array}$ & 0.9011347 & 0.8372588 & 0.7213203 & 0.7645575 & 0.7034355 \\
\hline
\end{tabular}

Figure 9 shows the calculated coefficient for all objects and values aggregated for every cluster. As the results show, all three clusters are of high quality.

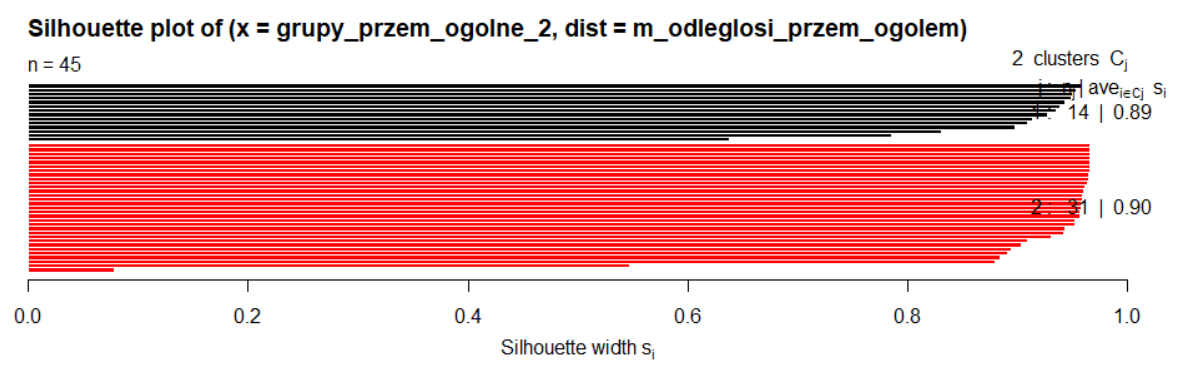

Average silhouette width : 0.9

Figure 9. The silhouette index for three clusters of similar NACE divisions with respect to the total share of industrial enterprises that introduced new or improved products or business processes

Table 11 presents NACE divisions divided into two clusters. The first cluster contains 14 NACE divisions, where it can be observed that the share of industrial enterprises introducing new or improved business processes is much higher in each NACE divisions than the share of industrial enterprises introducing new or improved products. The second cluster contains 32 NACE divisions, where it can be observed that the share of enterprises introducing new or improved business processes and products is at a similar level within each NACE division. 


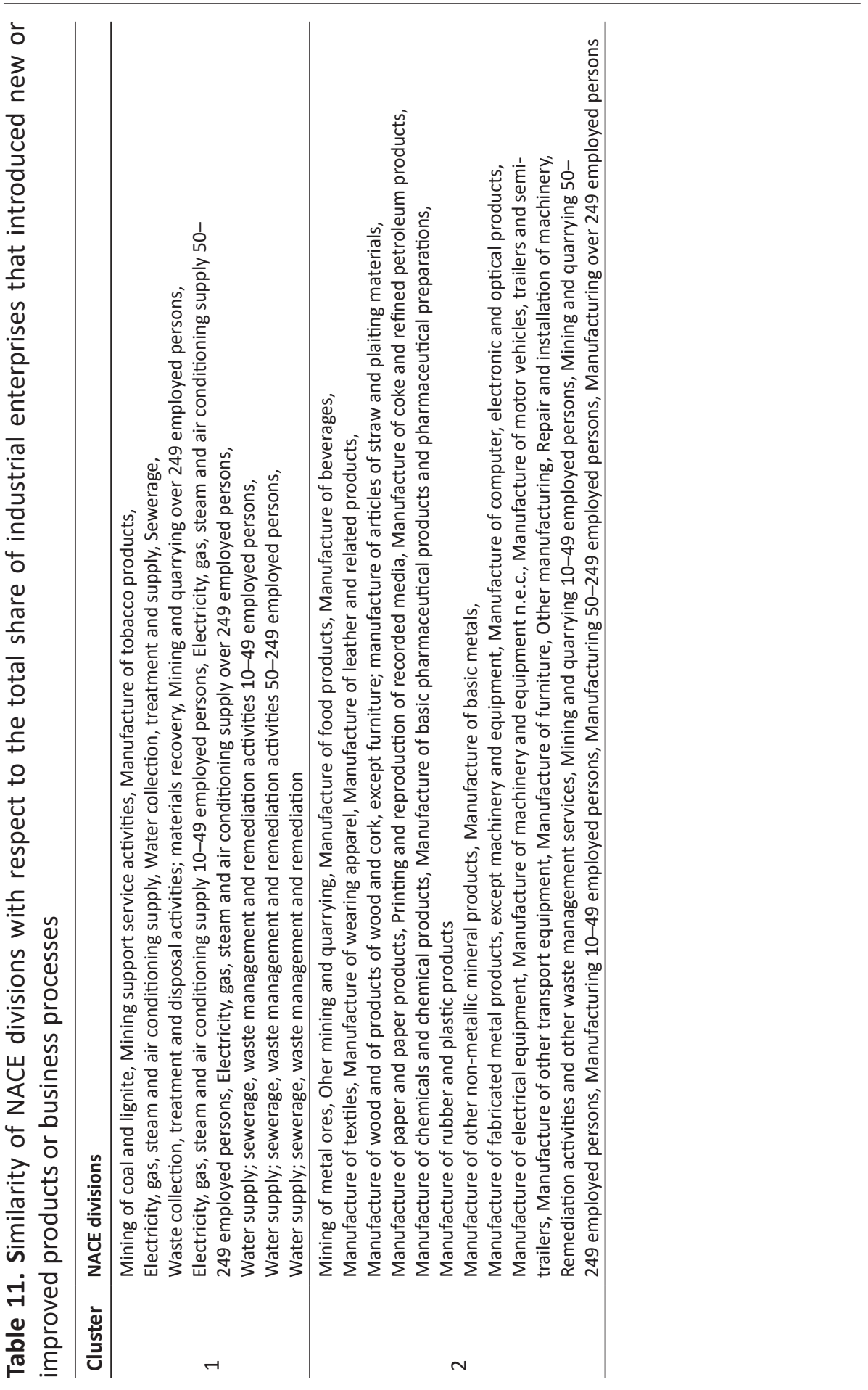


Innovation activity of industrial enterprises that introduced new or improved products

The cluster analysis of NACE divisions similar to each other in terms of the share of industrial enterprises that introduced new or improved products was the main goal of this stage of the analysis. The following variables were included in the analysis:

1) Share of enterprises that introduced new or improved goods.

2) Share of enterprises that introduced new or improved services.

3) Share of enterprises that introduced new or improved goods or services new to the market.

4) Share of enterprises that introduced new or improved goods or services new only to the enterprise.

For the cluster analysis, Ward's algorithm was used with the Cosine distance. The dendrogram obtained as a result is presented in Figure 10. 
Dendrogram of agnes $\left(x=m \_o d l e g l o s c i \_p r z e m \_p r o d\right.$, method $=$ "ward")

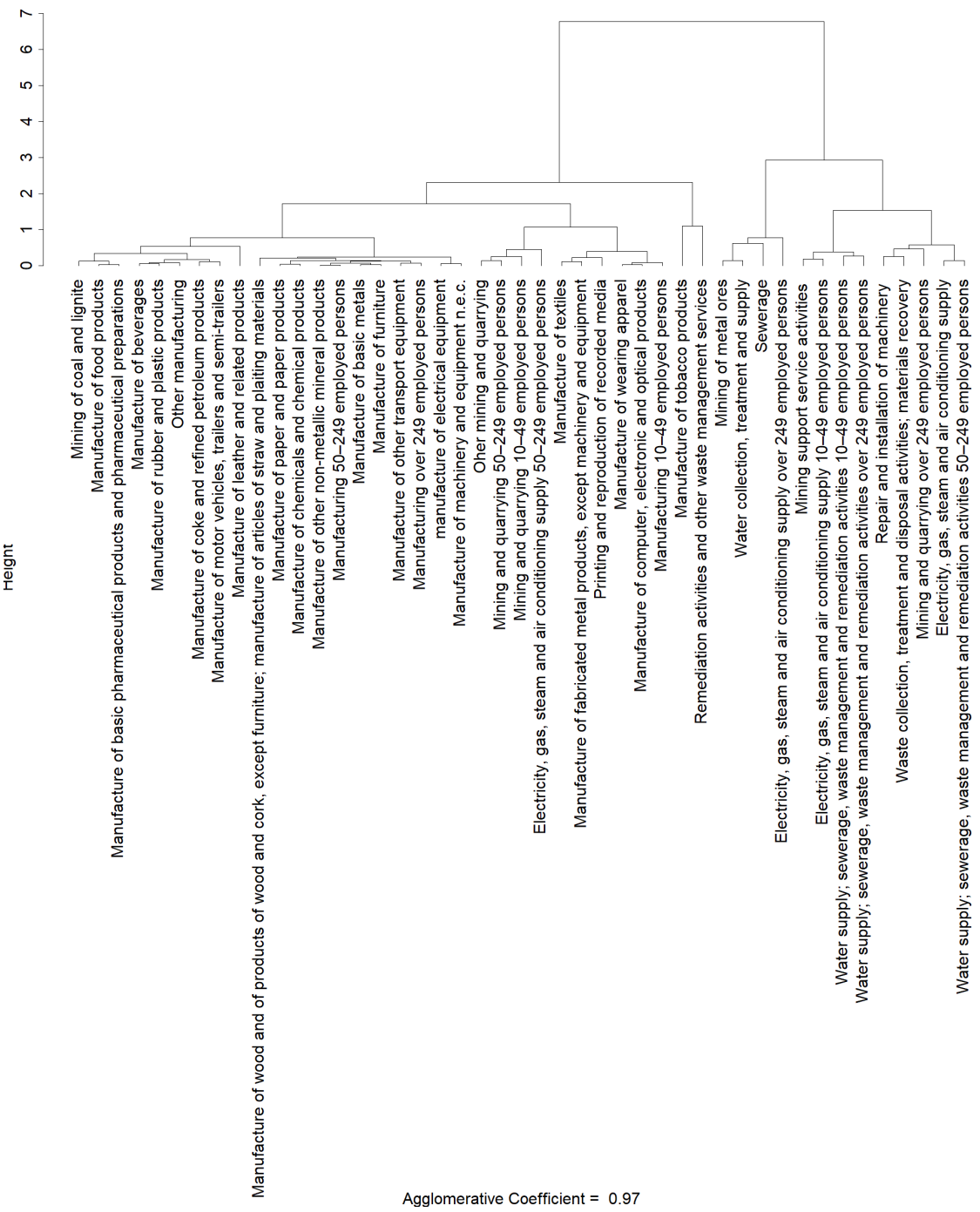

Figure 10. The similarity of NACE divisions with respect to the total share of industrial enterprises that introduced new or improved products

The next step in the analysis was to determine the appropriate number of clusters. The silhouette index was used to assess the quality of the division. As the results in Table 12 show, the best quality was found in the division of the surveyed population into two clusters. The silhouette index was 0.76 . 
Table 12. The silhouette index for the similarity of NACE divisions with respect to the total share of industrial enterprises that introduced new or improved products

\begin{tabular}{lccccc}
\hline & 2 groups & 3 groups & 4 groups & $\mathbf{5}$ groups & 6 groups \\
\hline $\begin{array}{l}\text { The } \\
\text { silhouette } \\
\text { index }\end{array}$ & 0.7628942 & 0.6287666 & 0.6333996 & 0.4387073 & 0.3772319 \\
\hline
\end{tabular}

Figure 11 shows the calculated coefficients for all objects and values aggregated for every cluster. As the results show, one of the clusters is of high quality and the second one presents a reasonable structure.

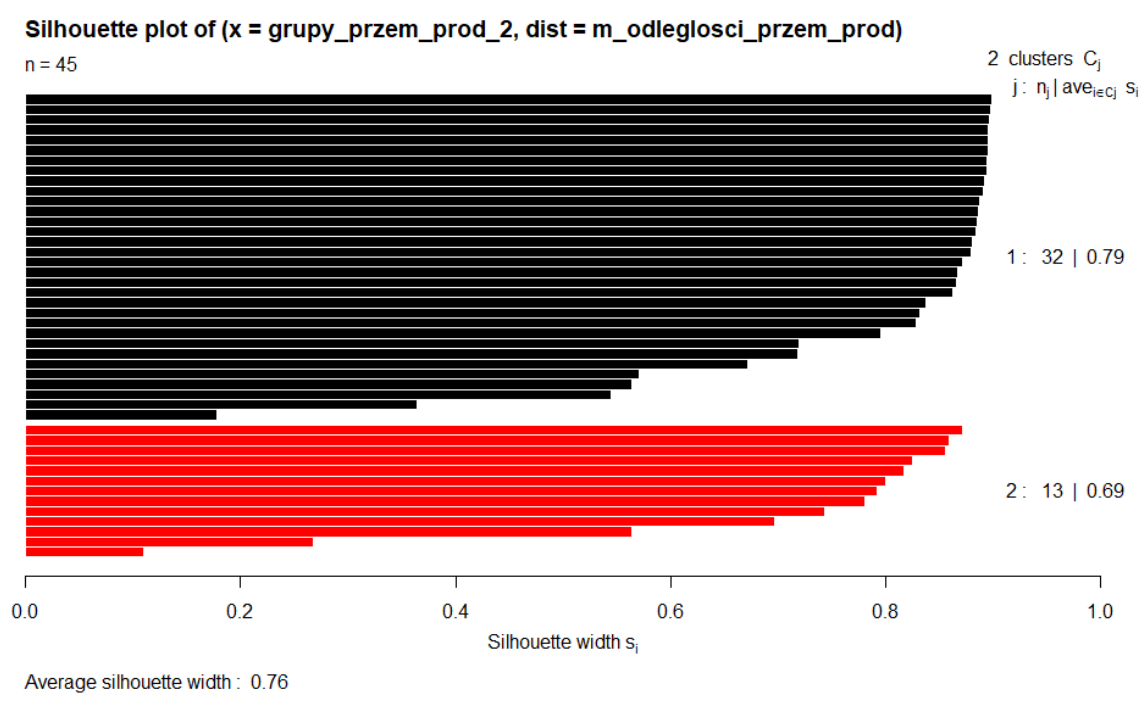

Figure 11. The silhouette index for two clusters of similar NACE divisions with respect to the total share of industrial enterprises that introduced new or improved products

According to the results, Table 13 shows the grouping of NACE divisions divided into two clusters. Based on the tables published by the Polish Central Statistical Office (GUS, 2020), it can be indicated that the first cluster is characterized by a high share of enterprises that introduce new and improved goods. In the case of the second cluster, the share of industrial enterprises that introduced new or improved goods is higher than the share of industrial enterprises that introduced new or improved services. 


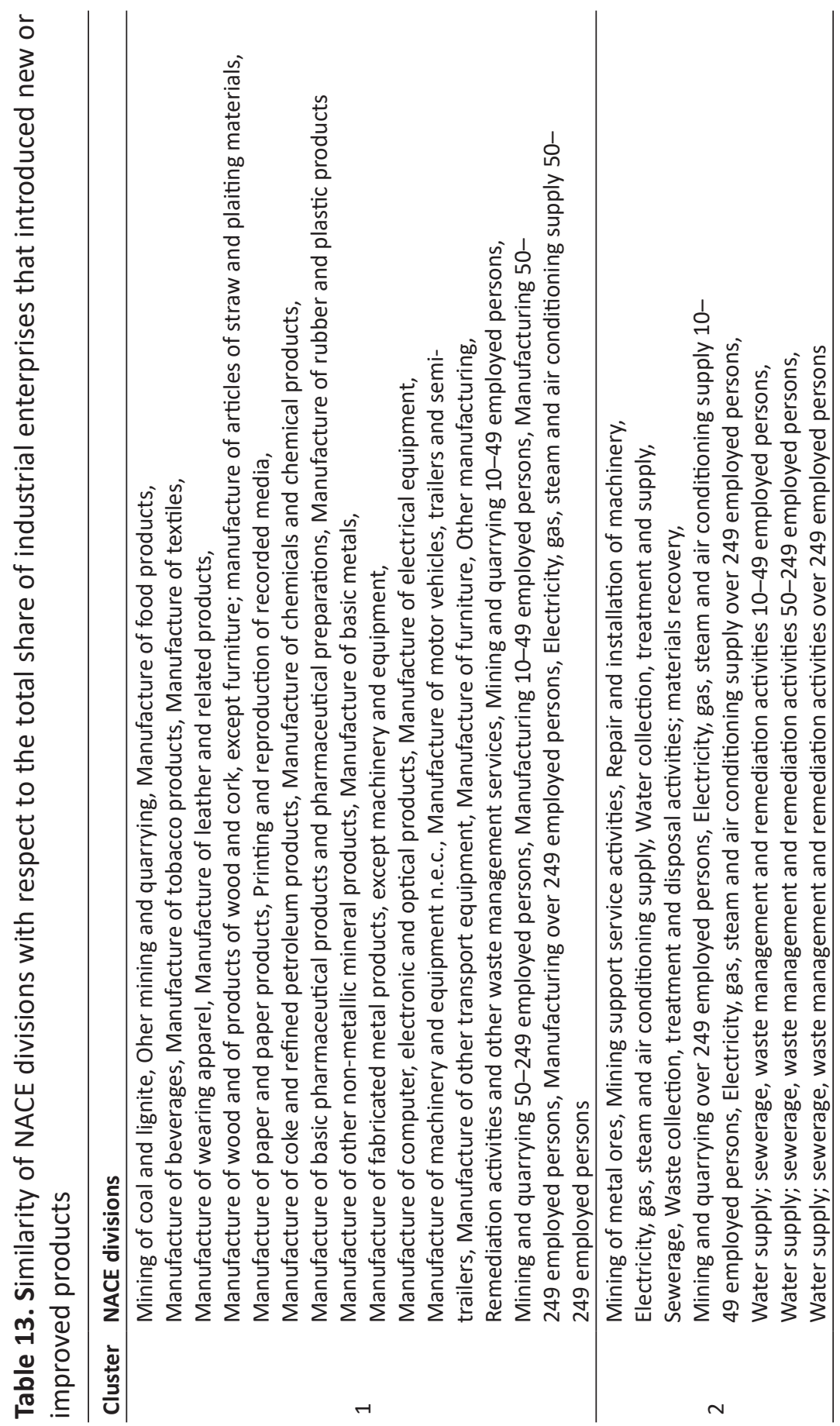

The Evolution of Strategic Management: Challenges in Theory and Business Practice Tomasz Kafel \& Bernard Ziębicki (Eds.) 
Innovation activity of industrial enterprises that introduced new or improved business processes

The cluster analysis of NACE divisions similar to each other in terms of the share of industrial enterprises that introduced new or improved business processes was the main goal of this stage of the analysis. The analysis included variables related to the share of industrial enterprises that introduced new or improved methods for:

1) Producing goods or providing services (including methods for developing goods or services).

2) Logistics, delivery or distribution.

3) Information processing or communication.

4) Accounting or other administrative operations.

5) Business practices for organizing procedures or external relations.

6) Organizing work responsibility, decision making or human resource management.

7) Marketing methods for promotion, packaging, pricing, product placement or after sales services.

For the cluster analysis, Ward's algorithm was used with the Cosine distance. The dendrogram obtained as a result is presented in Figure 12. 
Dendrogram of $\operatorname{agnes}\left(x=\mathbf{m} \_\right.$odleglosci_przem_pb, method = "ward")
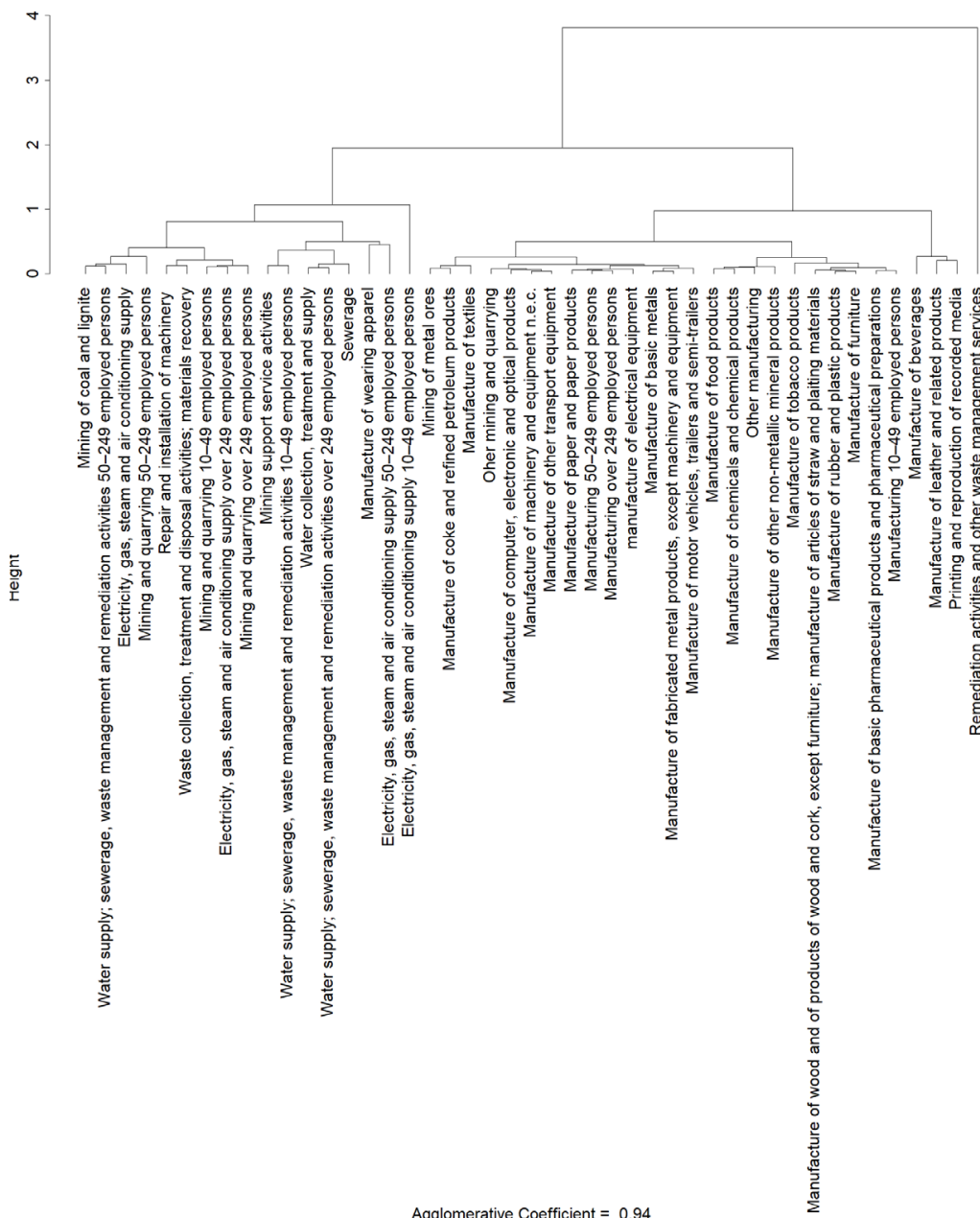

Figure 12. The similarity of NACE divisions with respect to the total share of industrial enterprises that introduced new improved business processes

The next step in the analysis was to determine the appropriate number of clusters. The silhouette index was used to assess the quality of the division. As the results in Table 14 show, the best quality was found in the division of the surveyed population into two clusters. 
Table 14. The silhouette index for the similarity of NACE divisions with respect to the total share of industrial enterprises that introduced new or improved business processes

\begin{tabular}{lccccc}
\hline & 2 groups & $\mathbf{3}$ groups & $\mathbf{4}$ groups & $\mathbf{5}$ groups & $\mathbf{6}$ groups \\
\hline $\begin{array}{l}\text { The } \\
\text { silhouette } \\
\text { index }\end{array}$ & 0.847214 & 0.5345078 & 0.4789247 & 0.360337 & 0.3084363 \\
\hline
\end{tabular}

Figure 13 shows the calculated coefficients for all objects and values aggregated for every cluster. The surveyed group was divided into two clusters. One of them is a one-element group and it concerns the NACE division:

Remediation activities and other waste management services. This is the only one of the analyzed NACE divisions that is characterized by the lack of introduced innovative methods for producing goods or providing services, logistics, delivery or distribution of logistics methods, accounting or other administrative operations, business practices for organizing procedures or external relations, marketing methods for promotion, packaging, pricing, product placement or after sales services. It is also characterized by a very low share of industrial enterprises that introduced new or improved innovation methods for information processing or communication (1.9\%) and organizing work responsibility, decision making or human resource management (3.7\%).

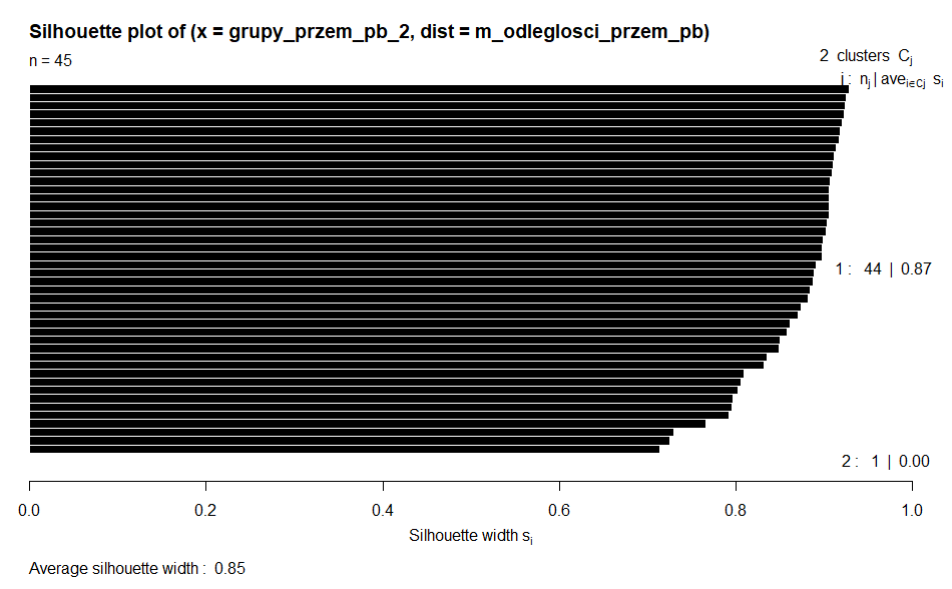

Figure 13. The silhouette index for two clusters of similar NACE divisions with respect to the total share of industrial enterprises that introduced new or improved business processes 


\section{Similarity of classifications}

The last stage of analysis was to measure the similarity between two data classifications using the Rand index. The results of this stage of analysis, for clustering NACE divisions with respect to the total share of enterprises that introduced new or improved products or business processes and separately for new or improved products and new or improved business processes, are shown for service enterprises in Table 15 and industrial enterprises in Table 16. The analysis of similarity took into account the division into two and three clusters in each case.

Table 15. Similarity of clustering NACE divisions with respect to the share of service enterprises: in innovation activity (product innovations or business processes innovations) that introduced new or improved products (product innovations) or business processes (business processes innovations)

\begin{tabular}{|c|c|c|c|c|c|c|}
\hline & $\begin{array}{l}\text { Product } \\
\text { innovations } \\
\text { or business } \\
\text { processes } \\
\text { innovations } \\
2 \text { clusters }\end{array}$ & $\begin{array}{l}\text { Product } \\
\text { innovations } \\
\text { or business } \\
\text { processes } \\
\text { innovations } \\
3 \text { clusters }\end{array}$ & $\begin{array}{l}\text { Product } \\
\text { innovations } \\
2 \text { clusters }\end{array}$ & $\begin{array}{l}\text { Product } \\
\text { innovations } \\
3 \text { clusters }\end{array}$ & $\begin{array}{l}\text { Business } \\
\text { processes } \\
\text { innovations } \\
2 \text { clusters }\end{array}$ & $\begin{array}{l}\text { Business } \\
\text { processes } \\
\text { innovations } \\
\mathbf{3} \text { clusters }\end{array}$ \\
\hline $\begin{array}{l}\text { Product innovations } \\
\text { or business processes } \\
\text { innovations } \\
2 \text { clusters }\end{array}$ & 1 & 0.6458333 & 0.5909091 & 0.4772727 & 0.6212121 & 0.655303 \\
\hline $\begin{array}{l}\text { Product innovations } \\
\text { or business processes } \\
\text { innovations } \\
\mathbf{3} \text { clusters }\end{array}$ & 0.6458333 & 1 & 0.5056818 & 0.5662879 & 0.782197 & 0.8162879 \\
\hline $\begin{array}{l}\text { Product innovations } \\
\mathbf{2} \text { clusters }\end{array}$ & 0.5909091 & 0.5056818 & 1 & 0.6780303 & 0.5909091 & 0.5871212 \\
\hline $\begin{array}{l}\text { Product innovations } \\
\mathbf{3} \text { clusters }\end{array}$ & 0.4772727 & 0.5662879 & 0.6780303 & 1 & 0.5568182 & 0.5833333 \\
\hline $\begin{array}{l}\text { Business processes } \\
\text { innovations } \\
\mathbf{2} \text { clusters }\end{array}$ & 0.6212121 & 0.782197 & 0.5909091 & 0.5568182 & 1 & 0.9431818 \\
\hline $\begin{array}{l}\text { Business processes } \\
\text { innovations } \\
\mathbf{3} \text { clusters }\end{array}$ & 0.655303 & 0.8162879 & 0.5871212 & 0.5833333 & 0.9431818 & 1 \\
\hline
\end{tabular}


Table 16. Similarity of clustering NACE divisions with respect to the share of industrial enterprises: in innovation activity (product innovations or business processes innovations) that introduced new or improved products (product innovations) or business processes (business processes innovations)

\begin{tabular}{|c|c|c|c|c|c|c|}
\hline & $\begin{array}{l}\text { Product } \\
\text { innovations } \\
\text { or business } \\
\text { processes } \\
\text { innovations } \\
2 \text { clusters }\end{array}$ & $\begin{array}{l}\text { Product } \\
\text { innovations } \\
\text { or business } \\
\text { processes } \\
\text { innovations } \\
3 \text { clusters }\end{array}$ & $\begin{array}{l}\text { Product } \\
\text { innovations } \\
2 \text { clusters }\end{array}$ & $\begin{array}{l}\text { Product } \\
\text { innovations } \\
3 \text { clusters }\end{array}$ & $\begin{array}{l}\text { Business } \\
\text { processes } \\
\text { innovations } \\
2 \text { clusters }\end{array}$ & $\begin{array}{l}\text { Business } \\
\text { processes } \\
\text { innovations } \\
\mathbf{3} \text { clusters }\end{array}$ \\
\hline $\begin{array}{l}\text { Product innovations } \\
\text { or business processes } \\
\text { innovations } \\
\mathbf{2} \text { clusters }\end{array}$ & 1 & 0.9505051 & 0.7979798 & 0.7838384 & 0.5454545 & 0.7727273 \\
\hline $\begin{array}{l}\text { Product innovations } \\
\text { or business processes } \\
\text { innovations } \\
\mathbf{3} \text { clusters }\end{array}$ & 0.9505051 & 1 & 0.7828283 & 0.7929293 & 0.4959596 & 0.7373737 \\
\hline $\begin{array}{l}\text { Product innovations } \\
\mathbf{2} \text { clusters }\end{array}$ & 0.7979798 & 0.7828283 & 1 & 0.9636364 & 0.5616162 & 0.7383838 \\
\hline $\begin{array}{l}\text { Product innovations } \\
\mathbf{3} \text { clusters }\end{array}$ & 0.7838384 & 0.7929293 & 0.9636364 & 1 & 0.5252525 & 0.720202 \\
\hline $\begin{array}{l}\text { Business processes } \\
\text { innovations } \\
\mathbf{2} \text { clusters }\end{array}$ & 0.5454545 & 0.4959596 & 0.5616162 & 0.5252525 & 1 & 0.5363636 \\
\hline $\begin{array}{l}\text { Business processes } \\
\text { innovations } \\
\mathbf{3} \text { clusters }\end{array}$ & 0.7727273 & 0.7373737 & 0.7383838 & 0.720202 & 0.5363636 & 1 \\
\hline
\end{tabular}

In the case of service enterprises, the highest values of the coefficients occurred for the division into two and three clusters according to the share of enterprises that introduced new or improved business process. The Rand index in this case was 0.9431818 . As for industrial enterprises, the highest value of the index concerned the division of the NACE divisions into two and three clusters, taking into account enterprises that introduced new or improved products. In this case, the Rand index was 0.9636364 .

\section{CONCLUSIONS}

The aim of this paper was to divide industries, classified according to NACE (the Statistical Classification of Economic Activities in the European Community) divisions, into groups that will be homogeneous in terms of the share of innovative enterprises. Based on the analyses carried out, the following conclusions can be drawn:

1) In the case of service enterprises, the best quality of the division was achieved when NACE divisions were separated into three clusters with 
respect to the total share of service enterprises that introduced new or improved products or business processes.

2) In the case of service enterprises, the best quality of the division was achieved when NACE divisions were separated into two clusters with respect to service enterprises that introduced new or improved products and with respect to the total share of service enterprises that introduced new or improved business processes.

3) The similarity of separating NACE divisions into two clusters, with respect to the share of service enterprises that introduced new or improved products (product innovations) or business processes (business processes innovations) is on average level. The Rand index in this case was 0.5909091.

4) In the case of industrial enterprises, the best quality of the division was achieved when NACE divisions were separated into two clusters.

5) The best quality of division was obtained in the case of separating NACE divisions with respect to the total share of industrial enterprises that introduced new or improved products or business processes. The silhouette index was 0.9011347.

6) The NACE divisions of Remediation activities and other waste management services are significantly different from the rest in terms of introducing new or improved business processes and are characterized by a very low share of enterprises introducing this kind of innovation.

Within the total share of service enterprises that introduced new, improved products or business processes, three clusters have been observed. The highest share in introducing product and business innovations concerns NACE divisions such as: Insurance, reinsurance and pension funding, except compulsory social security; Financial and insurance activities; Publishing activities; Programming and broadcasting activities; Telecommunications; Computer programming, consultancy, and related activities; Information service activities; Financial service activities, except insurance and pension funding; Activities auxiliary to financial services and insurance activities; Scientific research and development; Information and communication; and Professional, scientific and technical activity.

The second cluster is the smallest and contains only 5 NACE divisions: Land transport and transport via pipelines; Warehousing and support activities for transportation; Motion picture, video and television program production; Sound recording and music publishing activities; and Transporting and storage. This cluster has been presented by enterprises whose share in introducing new or improved products is rather low.

The third cluster contains 11 NACE divisions, where the share of enterprises introducing product innovations is rather on average level, with 
the three clusters of the lowest share being: Whole trade, except of motor vehicles and motorcycles; Postal and courier activities and Whole trade and retail trade, repair of motor vehicles including motorcycles. These industries have been presented by Water transport; Air transport; Architectural and engineering activities, technical testing and analysis; Advertising and market research; Transporting and storage over 249 employed persons; and Professional, scientific and technical activity.

Consequently, the analysis of the similarities in NACE divisions in terms of the share of innovative industrial enterprises has shown only two similar clusters.

The first cluster contains: Mining of coal and lignite; Mining support service activities, Manufacture of tobacco products; Electricity, gas, steam and air conditioning supply, Water collection, treatment and supply; Sewerage; Waste collection, treatment and disposal activities; Materials recovery; Mining and quarrying over 249 employed persons; and Water supply, sewerage, waste management, and remediation activities.

Whereas the second cluster contains: Manufacture of: computer, electronic, optical products and electrical equipment; Manufacture of motor vehicles and other transport equipment; Repair and installation of machinery; Manufacture of: food products, textiles, leather, wood and of products of wood, articles of straw and plaiting materials, paper and paper products, rubber and plastic products; Printing and reproduction of recorded media; Manufacture of chemicals and pharmaceutical; Manufacture of basic metals and other non-metallic mineral products; Manufacture of fabricated metal products; Remediation activities and other waste management services; Mining of metal ores; and Manufacture of coke and refined petroleum products.

Although the research procedure showed which enterprises belong to the groups of NACE divisions, it does not give us sufficient grounds to infer causality. It can be assumed that the similarity of a group may be a consequence of the amount of financial outlays, knowledge of products and services, use and level of support with IT tools, or extensive interorganizational cooperation.

Besides, divisions grouped into similar clusters may constitute a starting point for further in-depth analysis. However, some limitations of the conducted research should be pointed out. Firstly, the analysis carried out was based on data from a report published in January 2020 by the Polish Central Statistical Office and it concerns the innovative activity of enterprises in the years 2016-2018. Secondly, in the next stages of the research, it is crucial to verify whether, in previous years, NACE divisions were grouped into similar clusters. Lastly, an interesting direction of future research would be to try to create a ranking of industries in terms of the share of innovative 
enterprises introducing new or improved products or business processes and to check whether it reflects clusters of homogeneous industries.

\section{Acknowledgment}

The data used in the analysis come from a report published in January 2020 by the Polish Central Statistical Office - Innovative activity of enterprises in the years 2016-2018 (GUS, 2020). The research has been carried out as part of a research initiative financed by the Ministry of Science and Higher Education within "Regional Initiative of Excellence" Programme for 2019-2022. Project no.: 021/RID/2018/19. Total financing: 11,897,131.40 PLN.

\section{References}

Baldwin, J., \& Gelletly, G. (2003). Innovation Strategies and Performance in Small Firms. Cheltenham: Edward Elgar Publishing.

Białoń, L. (2010). Zarzqdzanie Działalnościq Innowacyjnq. Warszawa: Placet.

Bielińska-Dusza, E. (2020). Analysis of ground-breaking technologies and their effect on the functioning of enterprises. In I. Staniec \& A. ZakrzewskaBielawska (Eds.), Contemporary Challenges in Cooperation and Coopetition in the Age of Industry 4.0: 10th Conference On Management of Organizations' Development (Mod) (pp. 89-105). Springer Proceedings in Business and Economics. https://doi.org/10.1007/978-3-030-30549-9

Binti, S., Abidin, Z., Sanuri, S., Mokhtar, B., Zien, R., \& Yusoff, B. (2011). A systematic analysis of innovation studies: A proposed framework on relationship between innovation process and firm's performance. The Asian Journal of Technology Management, 4(2), 65-83. https://doi. org/10.12695/ajtm.2011.4.2.1

Block, J. H., Fisch, C. O., \& van Praag, M. (2017). The Schumpeterian entrepreneur: A review of the empirical evidence on the antecedents, behaviour and consequences of innovative entrepreneurship. Industry and Innovation, 24(1), 61-95. https://doi.org/10.1080/13662716.2016 .1216397

Bogdanienko, J. (2004). Innowacyjność Przedsiębiorstw. Toruń: TNOiK.

Bora, D. J., \& Gupta, A. K. (2014). Effect of different distance measures on the performance of K-means algorithm: An experimental study in Matlab. International Journal of Computer Science and Information Technologies, 5(2), 2501-2506. Retrieved from https://arxiv.org/abs/1405.7471

Bowonder, B., Dambal, A., Kumar, S., \& Shirodkar, A. (2010). Innovation strategies for creating competitive advantage. Research Technology Management, 53(3), 19-32. https://doi.org/10.1080/08956308.2010.1 1657628 
Branzei, O., \& Vertinsky, I. (2006). Strategic pathways to product innovation capabilities in SMEs. Journal of Business Venturing, 22(1), 75-105. https://doi.org/10.1016/j.jbusvent.2004.10.002

Casadeus-Masanell, R., \& Zhu, F. (2013). Business model innovation and competitive imitation: The case of sponsor-based business models. Strategic Management Journal, 34(4), 464-482. https://doi.org/doi. org/10.1002/smj.2022

Christensen, C. M. (2010). Przełomowe Innowacje. Warszawa: Wydawnictwo Naukowe PWN.

Conway, S., \& Steward, F. (2009). Managing and Shaping Innovation. Oxford: Oxford University Press.

Crossan, M. M., \& Apaydin, M. (2010). A multi-dimensional framework of organizational innovation: A systematic review of the literature. Journal of Management Studies, 47(6), 1154-1191. https://doi.org/10.1111/ j.1467-6486.2009.00880.x

Drost, H.-G. (2018). Philentropy: Information theory and distance quantification with R. Journal of Open Source Software, 3(26), 1-4. https://doi.org/10.21105/joss.00765

Dyduch, W. (2015). Innowacyjność strategiczna przedsiębiorstw w XXI w. Studia Ekonomiczne, Zeszyty Naukowe Uniwersytetu Ekonomicznego w Katowicach, 2(222), 19-33. Retrieved from http://yadda.icm.edu.pl/ yadda/element/bwmeta1.element.ekon-element-000171385059

Dyduch,W.(2018). Innowacyjnośćorganizacyjnaatworzenieiprzechwytywanie wartości. Prace Naukowe Uniwersytetu Ekonomicznego w Katowicach, 133-148. Retrieved from http://yadda.icm.edu.pl/yadda/element/ bwmeta1.element.ekon-element-000171521205

Elliott, R., Greenaway, D., \& Hine, R. (2000). Tests for factor homogeneity and industry classification. Weltwirtschaftliches Archiv, 136(2), 355-371.

Gadomski, R. (2004). Innowacje a konkurencyjność przedsiębiorstwa. Problemy Zarzqdzania, 2(1(3)), 20-31.

Gomułka, M. (2006). Innowacyjność polskiego przemysłu. In M.A. Weresa(Ed.), Polska. Raport o Konkurencyjności 2006. Rola Innowacji w Kształtowaniu Przewag Konkurencyjnych. Warszawa: Instytut Gospodarki Światowej, $\mathrm{SGH}$.

Gore, P. A. Jr. (2000). Cluster analysis. In H. E. A. Tinsley \& S. D. Brown (Eds.), Handbook of Applied Multivariate Statistics and Mathematical Modeling (pp. 297-321). San Diego, Kalifornia: Academic. Retrieved from https:// www.hse.ru/data/2012/01/04/1262163878/Gore Paul A. \%282000\%29 Cluster Analysis.pdf

Grzybowska, B. (2012). Innowacyjność Przemysłu Spożywczego w Polsce - Ujęcie Regionalne. Olsztyn: Wydawnictwo Uniwersytetu WarmińskoMazurskiego.

GUS. (2014). Działalność innowacyjna przedsiębiorstw w latach 2011-2013. Warszawa, Szczecin: Główny Urząd Statystyczny Urząd Statystyczny w Szczecinie. Informacje i opracowania statystyczne. Retrieved from 
https://stat.gov.pl/obszary-tematyczne/nauka-i-technika-spoleczenstwoinformacyjne/nauka-i-technika/dzialalnosc-innowacyjna-przedsiebiorstww-latach-2011-2013,2,8.html

GUS. (2018). Działalność innowacyjna przedsiębiorstw w latach 2014-2016. Warszawa, Szczecin: Główny Urząd Statystyczny Urząd Statystyczny w Szczecinie. Informacje i opracowania statystyczne. Retrieved from https://stat.gov.pl/obszary-tematyczne/nauka-i-technika-spoleczenstwoinformacyjne/nauka-i-technika/dzialalnosc-innowacyjna-przedsiebiorstww-latach-2014-2016,2,15.html

GUS. (2020). Działalność innowacyjna przedsiębiorstw w latach 2016-2018. Główny Urząd Statystyczny Urząd Statystyczny w Szczecinie. Informacje i opracowania statystyczne. Retrieved from https://stat.gov.pl/en/topics/ science-and-technology/science-and-technology/innovative-activity-ofenterprises-in-the-years-20162018,3,4.html

Han, J., Kamber, M., \& Pei, J. (2012). 2-Getting to know your data. In J. P. J. Han \& M. Kamber (Eds.), The Morgan Kaufmann Series in Data Management Systems, Data Mining (Third Edition) (pp. 39-82). Burlington, Massachusetts: Morgan Kaufmann Publishers. https://doi.org/10.1016/ B978-0-12-381479-1.00002-2

Hirsch-Kreisen, H., Hahn, K., \& Jacobson, D. (2008). The low-tech issue. In H. Hirsch-Kreisen \& D. Jacobson (Eds.), Innovation in Low-Tech Firms and Industries (pp. 3-85). Cheltenham: Edward Elgar Publishing.

Jakimowicz, A., \& Rzeczkowski, D. (2019). Diversification ofinnovation strategies of Polish industrial processing enterprises depending on their size after the global financial crisis. Journal of Entrepreneurship, Management and Innovation, 15(4), 35-76. https://doi.org/10.7341/20191542

Jalonen, H. (2012). The uncertainty of innovation: A systematic review of the literature. Journal of Management Research, 4(1), 1-47. https://doi. org/10.5296/jmr.v4i1.1039

Jansza, W., \& Kozioł-Nadolna, K. (2011). Innowacje w Organizacji. Warszawa: Polskie Wydawnictwo Ekonomiczne.

Karlik, M. (2013).Zarzq̨dzanie Innowacjami w Przedsiębiorstwie, Poszukiwanie i Realizacja Nowatorskich Projektów. Warszawa: Poltext.

Kay, J. (1996). Podstawy Sukcesu Firmy. Warszawa: Polskie Wydawnictwo Ekonomiczne.

Klimas, P. (2013). Wielowymiarowe ujęcie innowacyjności organizacyjnej. In J. Pyka (Ed.), Nowoczesność Przemysłu i Usług w Warunkach Kryzysu i Nowych Wyzwań (pp.169-180). Katowice: TNOiK.

Lemanowicz, M. (2014). Aktywność innowacyjna przedsiębiorstw w Polsce ze szczególnym uwzględnieniem branży spożywczej. Roczniki Naukowe Stowarzyszenia Ekonomistów Rolnictwa i Agrobiznesu, 16(6), 307-312. https://doi.org/10.22004 / ag.econ.205905

Llerene, P., \& Oltra, V. (2002). Diversity of innovative strategy as a source of technological performance. Structural Change and Economic Dynamics, 13(2), 179-201. https://doi.org/10.1016/S0954-349X(01)00036-4 
Low, J., \& Kalafut, P. C. (2004). Niematerialna Wartość Firmy. Ukryte Źródła Przewagi Konkurencyjnej. Kraków: Oficyna Ekonomiczna.

Łunarski, J. (2016). Innowacje Technologiczne w Przedsiębiorstwach. Projektowanie Wdrażanie i Użytkowanie. Warszawa: Instytut Mechanizacji Budownictwa i Górnictwa Skalnego.

Lynch, P., Walsh, M. M., \& Harrington, D. (2010). Defining and dimensionalizing organizational innovativeness. International CHRIE Conference-Refereed Track, 1-17. Retrieved from https://arxiv.org/abs/1405.7471http:// scholarworks.umass.edu/refereed/CHRIE_2010/Saturday/18\%5CnThis

Mallinguh, E., \& Zoltan, Z. (2020). Map of the existing research on business innovation, funding, and policy framework. Journal of Entrepreneurship, Management and Innovation, 16(2), 161-202. https://doi. org/10.7341/20201626

Mizgajska, H. (2002). Aktywność innowacyjna polskich małych i średnich przedsiębiorstw w procesie integracji z Unią Europejską. Prace Habilitacyjne Akademii Ekonomicznej w Poznaniu, 4.

Nogalski, B., \& Karpacz, J. (2012). Zdolność technologiczna jako źródło przewagi konkurencyjnej przedsiębiorstw produkcyjnych. Studia Ekonomiczne Regionu Łódzkiego, 173-185.

Okwiet, B., \& Grabara, J. K. (2013). Innovations' influence on SME's enterprises activities. Procedia Economics and Finance, 6, 194-204. https://doi. org/10.1016/s2212-5671(13)00132-9

OECD. (2005). Oslo Manual. Guidelines for collecting and interpreting innovation data. Vol. Third edit. Retrieved from https://ec.europa.eu/ eurostat/documents/3859598/5889925/OSLO-EN.PDF

Penc, J. (1999). Innowacje i Zmiany w Firmie. Transformacja i Sterowanie Rozwojem Przedsiębiorstwa. Warszawa: Agencja Wydawnicza Placet.

Pichlak, M. (2012). Uwarunkowania Innowacyjności Organizacji. Studium Teoretyczne i Wyniki Badań Empirycznych. Warszawa: Difin.

Pomykalski, A. (2001). Zarzq̨dzanie Innowacjami. Warszawa-Łódź: Wydawnictwo Naukowe PWN.

Poznańska, J. (2002a). Innowacyjność jako źródło przewagi konkurencyjnej polskich przedsiębiorstw. Materiały i Prace Instytutu Funkcjonowania Gospodarki Narodowej, 82(LXXXII), 65-79.

Poznańska, J. (2002b). Konkurencyjność a innowacyjność polskich przedsiębiorstw. Zeszyty Naukowe Akademii Ekonomicznej We Wrocławiu, 951, 204-211.

Prajogo, D. I., \& Ahmed, P. K. (2006). Relationships between innovation stimulus, innovation capacity, and innovation performance. $R$ and D Management, 36(5), 499-515. https://doi.org/10.1111/j.14679310.2006.00450.x

Rahimi, E., Rostami, N. A., Shad, F. S., \& Vafaei, V. (2017). The importance of knowledge management on innovation. Management Research Review, 5(1), 68-73. https://doi.org/10.1108/mrr-09-2015-0214 
Rousseeuw, P. J. (1987). Silhouettes: A graphical aid to the interpretation and validation of cluster analysis. Journal of Computational and Applied Mathematics, 20, 53-65. https://doi.org/10.1016/0377-0427(87)90125-7

Semerciöz, F., Hassan, M., \& Aldemir, Z. (2011). An empirical study on the role of interpersonal and institutional trust in organizational innovativeness. International Business Research, 4(2), 1-12. https://doi.org/10.5539/ibr. v4n2p125

Soni, N., \& Ganatra, A. (2012). Categorization of several clustering algorithms from different perspective: A review. International Journal of Advanced Research in Computer Science and Software Engineering, 2(8), 63-68.

Srholec, M., \& Verspagen, B. (2008). The voyage of the beagle in innovation system land. Explorations on sectors innovation, heterogeneity and selection (Vol. 008). Maastricht: UNU-MERIT.

Stawarz, E. (2013). Innowacja a konkurencyjność małych przedsiębiorstw. Zeszyty Naukowe Politechniki Łódzkiej. Organizacja i Zarzq̨dzanie, $1148(53), 17-27$.

Szatkowski, K. (2016). Zarzqdzanie Innowacjami i Transferem Technologii. Warszawa: Wydawnictwo Naukowe PWN.

Szekely, G., \& Rizzo, M. (2016). Hierarchical clustering via joint betweenwithin distances: Extending Ward's Minimum variance method. Journal of Classification, 22, 151-183. https://doi.org/10.1007/s00357-0050012-9

Szopik-Depczyńska K. (2018). Koncepcja innowacji. Kreowanej przez użytkownika w działaności badawczo-rozwojowej przedsiębiorstw. Rozprawy i Studia T. (MCXXI) 1047. Szczecin: Wydawnictwo Naukowe Uniwersytetu Szczecińskiego.

Urbankova, E., \& Krizek, D. (2020). Homogeneity of determinants in the financial sector and investment in EU countries. Economies, 8(1),1-17. https://doi.org/10.3390/economies8010014

Wang, C. L., \& Ahmed, P. K. (2004). The development and validation of the organisational innovativeness construct using confirmatory factor analysis. European Journal of Innovation Management, 7(4), 303-313. https://doi.org/10.1108/14601060410565056

Włodarczyk, R. (2017). Działalność innowacyjna polskich przedsiębiorstw. Zeszyty Naukowe Politechniki Częstochowskiej Zarzqdzanie, 25(2), 116126.

Wziątek-Kubiak, A. (2010). Zróżnicowanie wzorców działalności innowacyjnej przedsiębiorstw przemysłów o niskiej i wysokiej technologii. Analiza porównawcza. Studia Ekonomiczne. Economic Studies, 2(65), 141-168. Retrieved from https://www.inepan.pl/pliki/studia_ekonomiczne/Studia 2010202 Wziatek-Kubiak.pdf

Zartha, J. W. S., Montes, J. M. H., Vargas, E. E. M., Velez, E. E., Hoyos, J. L. C., Hernandez, R. Z., \& Novikova, O. (2016). Innovation strategy. Espacios, 37(24), 1-19. 
Zastempowski, M. (2013). Aktywność Innowacyjna Polskich Małych i Średnich Przedsiębiorstw. Toruń: Wydawnictwo Naukowe Uniwersytetu.

Zastempowski, M. (2016). Aktywność polskich małych i średnich przedsiębiorstw w budowaniu przestrzeni innowacyjnej. Studia Ekonomiczne. Zeszyty Naukowe Uniwersytetu Ekonomicznego w Katowicach, 267, 214-226.

\begin{abstract}
Abstrakt
Cel: Innowacyjność przedsiębiorstw uzależniona jest od wielu zmiennych, w tym od decyzji w zakresie innowacji, posiadanych zasobów i kompetencji, jak i sektora dziatalności. Powinna być rozpatrywana w wymiarze strategicznym, zarówno na poziomie innowacyjności strategicznej przedsiębiorstwa oraz ogólnej strategii. Innowacyjność strategiczna będqca długookresowym procesem uwzględniajqcym wzajemne przenikanie się różnych rodzajów innowacji wraz z myśleniem strategicznym może być skutecznym narzędziem uzyskiwania wysokiej efektywności działania oraz utrzymania przewagi konkurencyjnej na rynku. Analiza literatury przedmiotu, jak również obserwacje, wskazujq, że nawet w obrębie jednej branży występujq zróżnicowania pod tym względem. Celem autorów było dokonanie podziału branż klasyfikowanych według podziałów PKD na jednorodne grupy pod względem innowacyjności przedsiębiorstw w danej branży. Metodyka: W części empirycznej przedstawiono wyniki badań własnych metodq analizy skupień, natomiast wszystkie obliczenia wykonano w programie R. Wyniki: Na podstawie tych wyników można stwierdzić, że branże można pogrupować $w$ jednorodne klastry pod względem udziału innowacyjnych przedsiębiorstw. Wyniki przeprowadzonych badań wykazały, że klastry wyliczane na podstawie udziału firm innowacyjnych, które wprowadziły nowe lub ulepszone produkty oraz klastry notowane na podstawie udziału firm innowacyjnych, które wprowadziły nowe lub ulepszone procesy biznesowe, sq bardzo zbliżone. Implikacje dla teorii i praktyki: Wartościq dodanq rozważań przedstawionych $w$ artykule jest możliwość uzyskania dodatkowych informacji o jednorodności działalności innowacyjnej tych przedsiębiorstw w poszczególnych działach PKD. Wyniki te można wykorzystać do dalszej pogłębionej analizy poszczególnych grup. Oryginalność i wartość: Możemy odnaleźć wiele pozycji skupiajqcych się na problemie innowacyjności poszczególnych przedsiębiorstw, sektorów, branż, regionów. Brak jest natomiast opracowania prezentujqcego podobieństwo branż i podział na jednorodne grupy pod względem udziału innowacyjnych przedsiębiorstw. Luka ta, stała się inspiracja do badań, co pozwoliło zweryfikować problem naukowy.
\end{abstract}

Słowa kluczowe: strategia, strategia innowacji, sektor, klasyfikacja PKD, analiza skupień, podobieństwo

\title{
Biographical notes
}

Edyta Bielińska-Dusza, Ph.D., is Assistant Professor in the Dept. of Strategic Analysis of the Cracow University of Economics. Her research revolves around strategy, technology, internal audit, and inter-organizational phenomena. 
Her lectures are dedicated to strategy management, technology audit, and technology design and forecasting, including management methods and tools. She has been a co-organizer of Scientific Conferences and has served as an expert in various projects ("Revolution 4.0. Regional Initiative of Excellence," "Innovation Brokers as a tool for effective development," "First Business - Support to start," "The Rapid Response Instrument"). She has also participated in study visits and scientific workshops (Stanford University, University of Berkeley), and has certificates (École Polytechnique Fédérale de Lausanne, Switzerland; ISIS Innovation Ltd, Oxford; Strategic Business Insights, Stanford; PRINCE 1\&2).

Monika Hamerska, Ph.D., is Assistant in the Department of International Management. She received her Ph.D. in Social Science from Cracow University of Economics in 2019. The topic of the doctoral dissertation was related to the identification of determinants and modeling of scientific productivity. Her main research areas are scientific productivity, knowledge transfer, and decision optimization.

\section{Conflicts of interest}

The authors declare no conflict of interest.

\section{Citation}

Bielińska-Dusza, E., \& Hamerska, M. (2021). Innovative activity of Polish enterprises - a strategic aspect. The similarity of NACE divisions. Journal of Entrepreneurship, Management and Innovation, 17(2), 53-98. https://doi. org/10.7341/20211723 